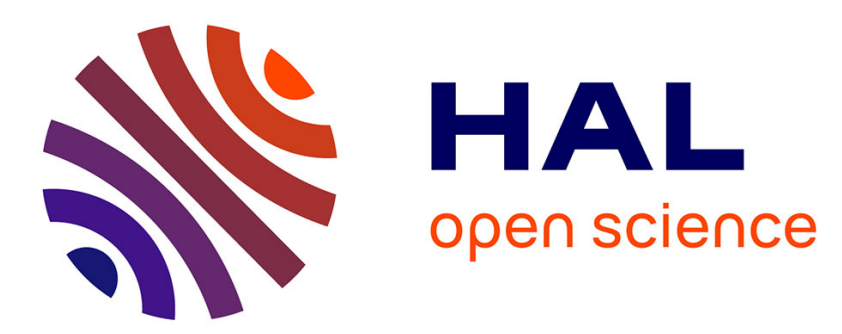

\title{
The Role of Crustal Strength in Controlling Magmatism and Melt Chemistry During Rifting and Breakup
}

\author{
John Armitage, Kenni Petersen, Marta Pérez-Gussinyé
}

\section{To cite this version:}

John Armitage, Kenni Petersen, Marta Pérez-Gussinyé. The Role of Crustal Strength in Controlling Magmatism and Melt Chemistry During Rifting and Breakup. Geochemistry, Geophysics, Geosystems, 2018, 19 (2), pp.534-550. 10.1002/2017GC007326 . insu-02920041

\section{HAL Id: insu-02920041 \\ https://hal-insu.archives-ouvertes.fr/insu-02920041}

Submitted on 5 Mar 2021

HAL is a multi-disciplinary open access archive for the deposit and dissemination of scientific research documents, whether they are published or not. The documents may come from teaching and research institutions in France or abroad, or from public or private research centers.
L'archive ouverte pluridisciplinaire HAL, est destinée au dépôt et à la diffusion de documents scientifiques de niveau recherche, publiés ou non, émanant des établissements d'enseignement et de recherche français ou étrangers, des laboratoires publics ou privés. 


\section{Geochemistry, Geophysics, Geosystems}

\section{RESEARCH ARTICLE \\ 10.1002/2017GC007326 \\ The Role of Crustal Strength in Controlling Magmatism and Melt Chemistry During Rifting and Breakup}

Key Points:

- A difference in crustal strength leads to a different rate of depletion in light elements relative to heavy elements

- The numerical model of continental breakup can reproduce observations of melt chemistry from the Basin and Range if the lower crust is weak - The model can also match melt compositions from the Main Ethiopian Rift only if the lower crust is strong

Supporting Information: - Supporting Information S1

Correspondence to:

J. J. Armitage,

armitage@ipgp.fr

\section{Citation:}

Armitage, J. J., Petersen, K. D., \& Pérez-Gussinyé, M. (2018). The role of crustal strength in controlling magmatism and melt chemistry during rifting and breakup. Geochemistry, Geophysics, Geosystems, 19, 534-550. https://doi.org/10.1002/2017GC007326

Received 13 NOV 2017 Accepted 29 JAN 2018 Accepted article online 6 FEB 2018 Published online 27 FEB 2018 the strength of the continental crust, weak crust gives a wide rift and vica-versa, yet such relations are

\author{
John J. Armitage ${ }^{1}$ (D), Kenni D. Petersen² (D), and Marta Pérez-Gussinyé3 ${ }^{\text {(D) }}$ \\ ${ }^{1}$ Dynamique des Fluides Géologiques, Institut de Physique du Globe de Paris, Paris, France, ${ }^{2}$ Department of Geoscience, \\ University of Aarhus, Aarhus, Denmark, ${ }^{3}$ MARUM, University of Bremen, Bremen, Germany
}

\begin{abstract}
The strength of the crust has a strong impact on the evolution of continental extension and breakup. Strong crust may promote focused narrow rifting, while wide rifting might be due to a weaker crustal architecture. The strength of the crust also influences deeper processes within the asthenosphere. To quantitatively test the implications of crustal strength on the evolution of continental rift zones, we developed a 2-D numerical model of lithosphere extension that can predict the rare Earth element (REE) chemistry of erupted lava. We find that a difference in crustal strength leads to a different rate of depletion in light elements relative to heavy elements. By comparing the model predictions to rock samples from the Basin and Range, USA, we can demonstrate that slow extension of a weak continental crust can explain the observed depletion in melt chemistry. The same comparison for the Main Ethiopian Rift suggests that magmatism within this narrow rift zone can be explained by the localization of strain caused by a strong lower crust. We demonstrate that the slow extension of a strong lower crust above a mantle of potential temperature of $1,350^{\circ} \mathrm{C}$ can fit the observed REE trends and the upper mantle seismic velocity for the Main Ethiopian Rift. The thermo-mechanical model implies that melt composition could provide quantitative information on the style of breakup and the initial strength of the continental crust.
\end{abstract}

Plain Language Summary There are various regions within the continents today that appear to be extending and breaking apart, known as rifts. There are examples of regions where the extension is distributed over hundreds of kilometres, such as the Basin and Range in North America. There are also regions of narrow focused extension such as the Main Ethiopian Rift. Both these example regions also have a history of magmatism, with basaltic rocks outcropping at the surface. The width of a rift can be related to subjective. In this study we explore if the chemical composition of the erupted basaltic rocks is a function of the crustal strength. We developed a numerical model that approximates the extension of the upper mantle, including the continental crust. Our model finds that the magmatism in the wide Basin and Range can be explained by the break-up of a weak continental crust. The same model would suggest that the magmatism observed in Ethiopia is due to extension of a strong continental crust. Such a result is contentious, as previous studies have suggested that both regions have weak continental crust.

\section{Introduction}

The style of continental extension and the architecture of crustal faulting is related to the strength and thickness of the continental lithosphere and crust (e.g., Brun, 1999; Brune et al., 2017a; Buck, 1991; Huismans \& Beaumont, 2011; Ros et al., 2017). It has been proposed that a weak lower crust could lead to a core complex or wide rift typified by the Basin and Range in the southwest U.S., while a strong lower crust could lead to a narrow rift such as the Baikal Rift (e.g., Buck, 1991). However, structural and geophysical studies of passive margins have lead to the argument that breakup is necessarily complex and multi-phase (Armitage et al., 2010; Brune et al., 2014; Lavier \& Manatschal, 2006; Peron-Pinvidic et al., 2013; Ranero \& PérezGussinyé, 2010). To try and classify breakup, a series of types have been generated, based mostly on numerical model cross sections and tectonic reconstructions (e.g., Huismans \& Beaumont, 2011). These have proven useful for classing model evolution as a function of crustal rheology and rates of extension (e.g., Svartman Dias et al., 2015; Tetreault \& Buiter, 2017). (c) 2018. American Geophysical Union All Rights Reserved. 
Classifying the style of breakup is however somewhat subjective. Furthermore, within the East African Rift zone, the narrowness of rifting at the Main Ethiopian Rift has been attributed to pre-existing weak zones, rather than the integrated strength of the crust and lithosphere (e.g., Keranen et al., 2009). This inference is based on the low seismic velocity of the upper crust and mantle, which is related to its temperature, mineral assemblage, and hence strength. Based on the joint inversion of Rayleigh waves and receiver functions it was inferred that the Main Ethiopian Rift is a narrow rift within a hot and weak continental lithosphere (Keranen et al., 2009). However, seismic velocity is also strongly influenced by the presence of melt, for which there is abundant evidence within the Main Ethiopian Rift (e.g. Bastow et al., 2005; Biggs et al., 2011; Whaler \& Hautot, 2006). Therefore, it is questionable as to if we can use present day seismic evidence from an active rift to infer the pre-rift crustal strength.

The quantity and composition of magmatic eruptions can be related to the mantle temperature and the duration of extension (e.g., Armitage et al., 2010; Bown \& White, 1995; Davis \& Lavier, 2017; Pérez-Gussinyé et al., 2006; Petersen \& Schiffer, 2016; Reston \& Phipps Morgan, 2004). Given that the style of breakup is strongly influenced by the crustal rheology, it is plausible that the melt composition and volume is likewise influenced by the crustal strength, and, for example, it has recently been demonstrated that crustal strength strongly influences the onset and amount of melt during rifting at ultra-slow spreading velocities (Ros et al., 2017). This raises the possibility that melt chemistry can be used in conjunction with geophysical observations to quantitatively constrain how crustal rheology could control breakup. In order to test the hypothesis that crustal strength impacts melt production during breakup, we develop a 2-D numerical model of extension of the crust and upper mantle, which can predict the volume and composition of melts generated during extension. We focus on the prediction of melt composition in terms of three rare Earth elements, Lanthanum (La), Samarium (Sm) and Ytterbium (Yb), as the ratios $\mathrm{La} / \mathrm{Yb}$ and $\mathrm{Sm} / \mathrm{Yb}$ are commonly used geochemical studies to assess the depth of melting and the degree of depletion.

We compare model predictions against dated observed rock chemistry in the Southern Basin and Range, which displays evidence of distributed faulting and is classically interpreted to be a wide rift zone (Buck, 1991; Hamilton, 1987). We therefore expect that model predictions of melt composition from a model with a weak continental crust would agree more with the age-composition trend of the melts erupted within the Basin and Range. We subsequently explore how the models might inform our understanding of breakup in the southern Gulf of California, which is also considered by some to a be a wide margin (e.g., Sutherland et al., 2012). Finally we apply the same model to the Main Ethiopian Rift, a narrow rift zone within the East African Rift.

\section{Methods}

We solve for the viscous, elastic, and plastic deformation of the lithosphere and asthenosphere, and the associated decompression melting using the model of Petersen et al. (2015), for full details see the supporting information. We assume a mantle potential temperature of either $1,350,1,400$, or $1,450^{\circ} \mathrm{C}$, and the rate of extension is between 5 and $100 \mathrm{~mm} \mathrm{yr}^{-1}$. We model decompression melting, $\frac{D F}{D t^{\prime}}$ using the melting relationships of Katz et al. (2003), assuming an initial water content of $100 \mathrm{ppm}$. Here, $\frac{D F}{D t^{\prime}}$, is defined as the rate of increase in fraction of melt at a material point. The water concentration of the solid mantle, $C_{S}$, is depleted from the mantle source assuming fractional crystalization:

$$
\frac{D C_{S}}{D t}=\left(1-\frac{1}{D}\right) C_{s} \frac{D F}{D t}
$$

where $D$ is the partition coefficient, which for water is taken to be $D=0.01$. The form of the partition coefficient for REE elements is described below.

Major element oxides and rare-Earth elements (REE) are sensitive to the depth of partial melting and the temperature of the mantle. The major element oxides can however become altered during the eruption of the rock. In contrast REE ratios are relatively unaltered during eruption. The enrichment of Lanthanum (La), Samarium $(\mathrm{Sm})$ and Ytterbium $(\mathrm{Yb})$ are therefore tracked using the partition coefficients of Salters and Stracke (2004) and mineral assemblages of Gibson and Geist (2010). We chose these three elements as the ratios of $\mathrm{La}$ and $\mathrm{Sm}$ to $\mathrm{Yb}$ can be used to estimate the depth of melting. A high La/Yb may indicate a greater proportion of deep melt production as La has a partition coefficient that is significantly lower than $\mathrm{Yb}$, or 
equally the melting of a source that is already depleted in $\mathrm{Yb}$. A high $\mathrm{Sm} / \mathrm{Yb}$ may suggest a larger proportion of melting in the presence of garnet, due to the relative difference in partition coefficients between the shallower mineral assemblages (e.g., Putrika, 1999).

We assume an initial primitive mantle composition given by McDonough and Sun (1995). Depletion of the solid composition is solved for using equation (1), where rather than a constant partition coefficient, $D$ is a function of the mineral phase stability (McKenzie \& O'Nions, 1991):

$$
D=f_{o l} \mathcal{D}_{o l \rightarrow m e l t}+f_{o p x} \mathcal{D}_{o p x \rightarrow m e l t}+f_{c p x} \mathcal{D}_{c p x \rightarrow \text { melt }}+f_{X} \mathcal{D}_{X \rightarrow \text { melt }}
$$

where $f$ is the proportion of each mineral within plagioclase, spinel, and garnet peridotite, $\mathcal{D}$ is the REE element partition coefficient from each mineral phase to melt, and $X$ represents, plagioclase, spinel, and garnet, respectively. The values for $f$ and $\mathcal{D}$ are taken from Gibson and Geist (2010), and mineral phase stability (plagioclase, spinel, or garnet peridotite) is a function of pressure and depth following McKenzie and O'Nions (1991), see the supporting information. Melt composition, $C_{M}$, is then given by,

$$
C_{M}=\frac{C_{S}}{D}
$$

Following Behn and Grove (2015) we calculate the average melt composition weighted by the melt production rate. We also estimate the crustal thickness assuming all of the melt generated is erupted at the center of extension following the method of Ito et al. (1996).

In order to test the effect of the strength of the crust on the evolving rift system we present models with two different crustal rheologies (Figure 1). We define a strong and a weak lower crust, respectively, following Schmalholz et al. (2009), where the weak lower crust is based on the experimentally derived properties of diabase (Afonso \& Ranalli, 2004), and the strong lower crust is the Columbia diabase from Mackwell et al. (1998; see Table 1 of the supporting information). The upper crust is wet quartzite (Ranalli, 1995), and a combined diffusion/dislocation creep dry olivine flow law based on Karato and Wu (1993) is assumed for both the lithosphere and asthenosphere (see Petersen et al., 2015). While the parameter values are based on limited experimental evidence, the important point is that the difference in lower crustal strength is six orders of magnitude between the strong and weak case (Schmalholz et al., 2009).

Not only lower crustal rheology controls rift evolution. Numerous studies also indicate that initial crustal thickness and thermal structure indirectly affect lower crustal strength and therefore rift evolution (e.g., Brun, 1999; Brune et al., 2017a; Buck, 1991; Huismans \& Beaumont, 2011; Petersen \& Schiffer, 2016; Ros

(a)

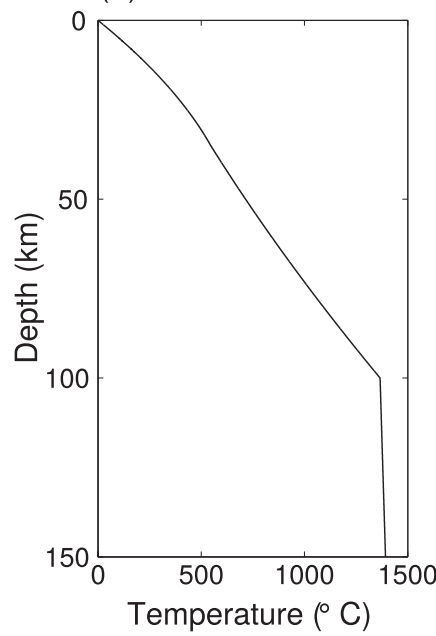

(b)

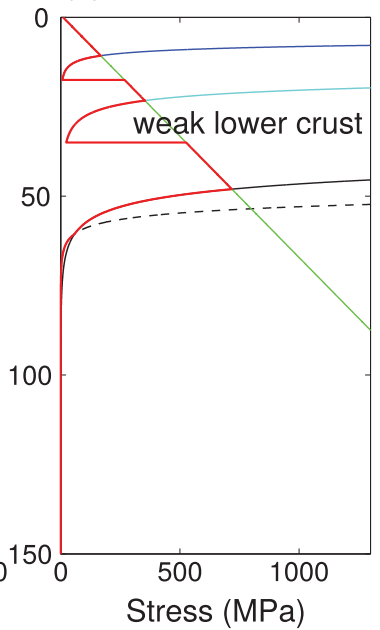

(c)

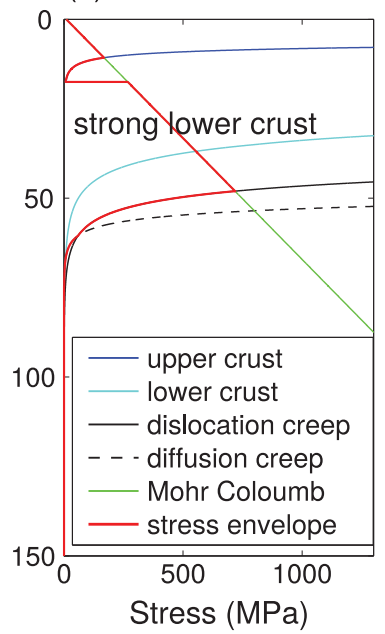

Figure 1. Strength profiles of the different models. (a) Example geotherm for the uppermost asthenosphere and lithosphere. (b) Stress-depth profile for the weak lower crust model. (c) Stress-depth profile for the strong lower crust model. The red line shows the strength envelope, the green line shows the Mohr Colomb failure, the pale blue line shows the viscous flow law for the lower crust, the solid black line shows the dislocation creep law for the mantle, and the dashed black line shows the diffusion creep law. 
et al., 2017). Here we focus exclusively on the effect of crustal strength due to compositional differences, but note that varying crustal thickness and/or thermal structure could have similar effects. For example, in a recent study it was shown that, while a change in lower crustal thickness does influence the onset of melt generation during breakup, it was the change in crustal rheology that had the largest effect on magmatism (Ros et al., 2017). Finally, it is hard to accurately know the initial thermal structure of the crust, its thickness, and rheology, as this crust will have been heavily modified (e.g., Ebinger et al., 2017). Therefore, in this study we will only vary the lower crustal rheology in order to explore the effect of different initial crustal strengths.

The numerical model consists of a domain that is initially 2,000 km long by $600 \mathrm{~km}$ deep. The uppermost $40 \mathrm{~km}$ is a sticky air layer used to allow the topography of the model domain to evolve with a approximation to a free surface (see Crameri et al., 2012; Petersen et al., 2010). The crust below is $35 \mathrm{~km}$ thick and split equally into an upper and lower crust (Figure 1). The lithosphere is initially $100 \mathrm{~km}$ thick. Extension is modeled by deforming the model domain by stretching it at a constant rate of extension at the right hand boundary. The model contains an initial perturbation to localize thinning of the crust. This perturbation takes the form of a region $2 \mathrm{~km}$ wide in the center of the $x$-axis where the crust thickens from 35 to $40 \mathrm{~km}$ in the form of a Gaussian curve.

To explore whether first-order effects observed in our somewhat complicated 2-D model can be explained by simpler means, quantitatively and conceptually, we also calculate melt productivity and composition along 1-D adiabatic melt paths (e.g., Phipps Morgan, 2001). We assume a constant rate of up-welling in a vertical column. The base of the column is at a depth of $300 \mathrm{~km}$ and the mantle potential temperature is $1,350^{\circ} \mathrm{C}$. The top boundary is a flow through boundary, with a depth at either 30 or $50 \mathrm{~km}$. This has the effect of limiting how shallow melt production can occur. Melting occurs when the temperature exceeds the solidus. For the 1-D model we use the linear solidus of Phipps Morgan (2001), where it is a function of temperature and depletion. Depletion and the mantle source composition are advected upward at the uniform up-upwelling rate. Using this approach, the effect of a reminiscent lid of continental crust superimposing the melt-generating mantle can be studied and compared with 2-D predictions.

\section{Results}

\subsection{Melt Generation, Crustal Strength and Mantle Temperature}

The time of the onset of melting depends on the strength of the crust (Figures 2 and $4 \mathrm{a}$ ). This is because the strength of the crust influences the rate at which it thins locally, and hence the vertical flow of the lithosphere and asthenosphere. If the crust is strong, shear bands develop through the lower crust and strain localizes in the viscous lithosphere (Figures $2 a-2 c$ ). Together with the evolving lateral density contrast between the asthenosphere and lithosphere, a positive feedback is generated leading to rapid thinning and the onset of melt production (Buck, 1991; Huismans \& Beaumont, 2003). If the lower crust is weak, then strain in the upper and lower crust is less localized and they deform through viscous flow (Figure 2d; Buck, 1991). The crust is capable of flowing at a timescale similar to that of extension. This leads to a protracted phase of extension where a wide rift forms at the surface (Buck, 1991), and more localized strain is produced in the mantle (Figures 2e and $2 \mathrm{f}$ ). As a consequence, decompression melting is delayed.

The growth of the zone of partial melting is plotted as the total volume of melt erupted at the center of extension (Figure 3). We also plot the minimum thickness of the stretched continental crust (upper and lower) against time in Figure 3. Assuming a mantle potential temperature of $1,350^{\circ} \mathrm{C}$, for a strong lower crust, we find that the crust thins to zero within $10 \mathrm{Myr}$ at an extension rate of $15 \mathrm{~mm}$ yr (Figure 3b, yellow line). If the crust is weak, the equivalent thinning takes 20 Myr (Figure 3b, dark blue line). Melt production mirrors this trend, with the steady state thickness achieved within 10 Myr for the model with strong lower crust compared to 20 Myr for the weak lower crust.

The duration of the extended period of thinning for weak crust is altered for hotter mantle conditions. At a mantle potential temperature greater than $1,400^{\circ} \mathrm{C}$ convective breakdown of the lithosphere influences melt production (cf. Simon et al., 2009). If the potential temperature is increased to $1,400^{\circ} \mathrm{C}$ (pale blue and orange lines in Figure 3 parts $a$ and $b$ ) then melt in excess of the steady state is produced as the crust is thinned. The predicted thickness of igneous rock reaches more than $20 \mathrm{~km}$ due to the convective breakdown of the lithosphere (Figure 4). For a potential temperature of $1,450^{\circ} \mathrm{C}$ the convective break-down is so 


\section{QAGU Geochemistry, Geophysics, Geosystems}

(a)

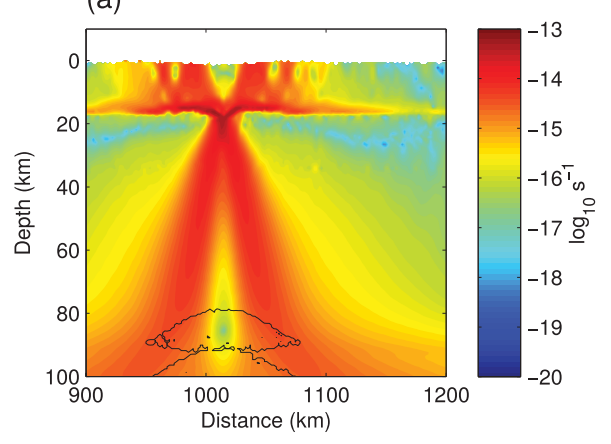

(d)

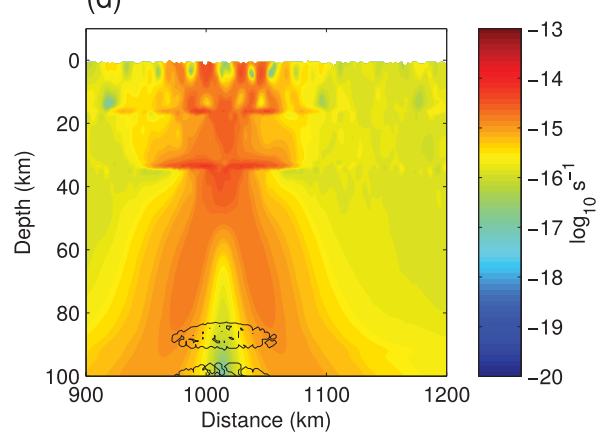

(b)

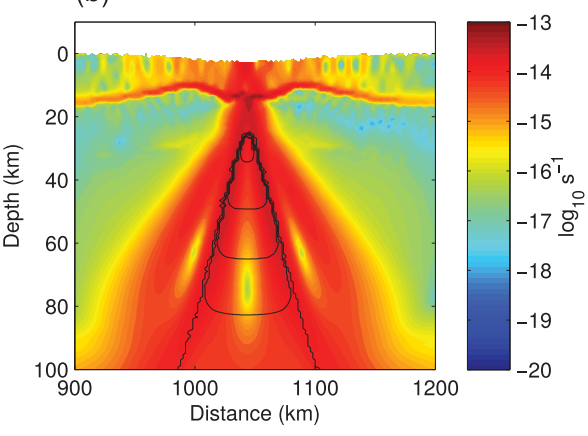

(e)

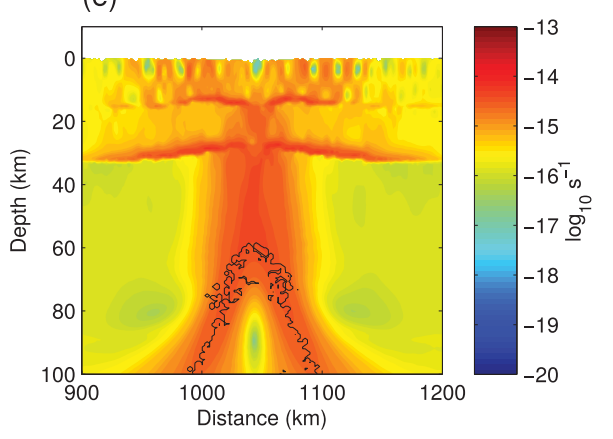

(c)

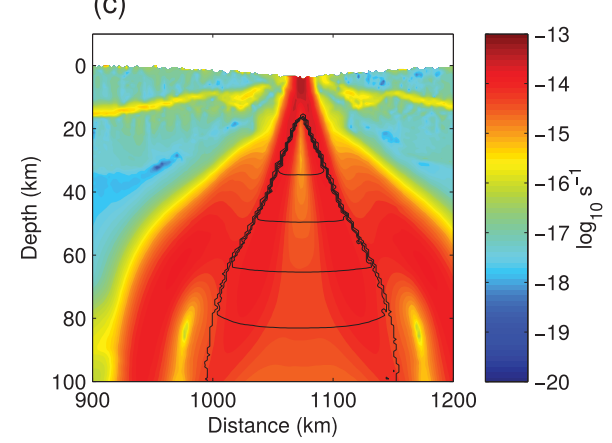

(f)

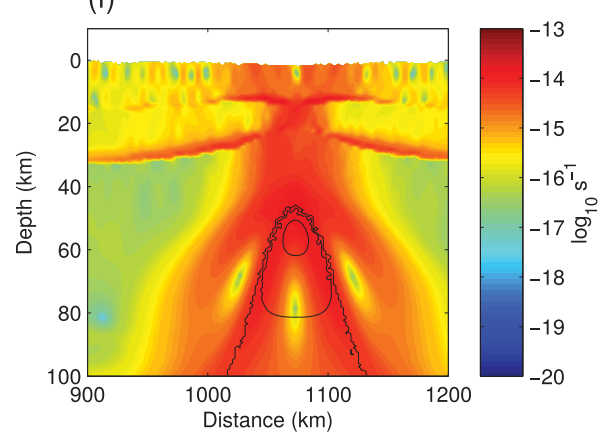

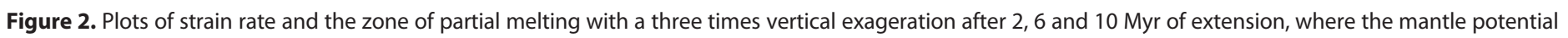
temperature is $1,400^{\circ} \mathrm{C}$. (a to c) Strong lower crust and ( $\mathrm{d}$ to $\mathrm{f}$ ) weak lower crust. Melt fraction by mass is contoured at intervals of 0.05 from 0 to 0.2 .

strong, given the larger temperature difference from the surface to the base of the lithosphere, that an exceptionally large amount of melt production is predicted (Figure $3 a$, red and green lines).

\subsection{Influence of Rate of Extension}

In ancient rifted margins, the duration of extension can be very difficult to estimate, as magnetic reversals may not be present, and dating the sedimentary sequences may not be possible. It is however possible to estimate the stretching factor from active seismic experiments (e.g., Bown \& White, 1995). Using the minimum thickness of the continental crust during extension to calculate a stretch factor, $\beta$, the volcanism

(a)

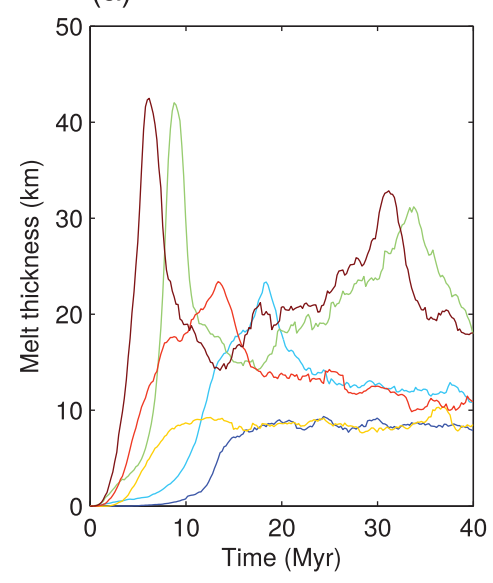

(b)

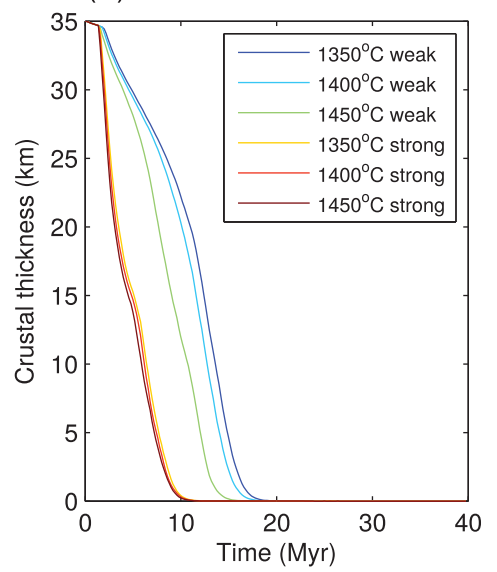

(c)

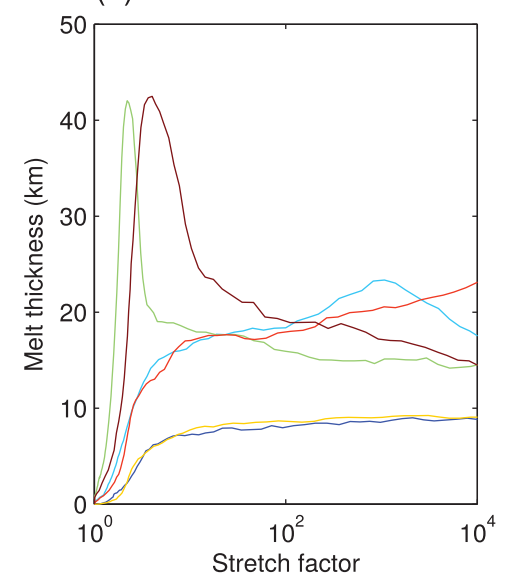

Figure 3. Model evolution for change in crustal strength, mantle potential temperature and rate of extension. (a) Melt thickness plotted against time for a set of six models that are all of an extension rate of $15 \mathrm{~mm} \mathrm{yr}^{-1}$. The mantle temperature is either $1,350,1,400$ or $1,450{ }^{\circ} \mathrm{C}$ and the lower crust is either strong or weak (see Figure 1). (b) Minimum crustal thickness as it thins due to extension plotted against time for the same set of models as in part a. (c) Melt thickness as a function of stretch factor for the same set of model as in part a. 


\section{QAGU Geochemistry, Geophysics, Geosystems}

(a) $\mathrm{Tp}=1400^{\circ} \mathrm{C}$, Time $=8.0 \mathrm{Myr}$

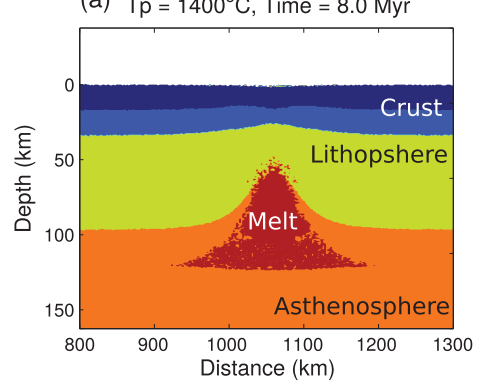

(d)

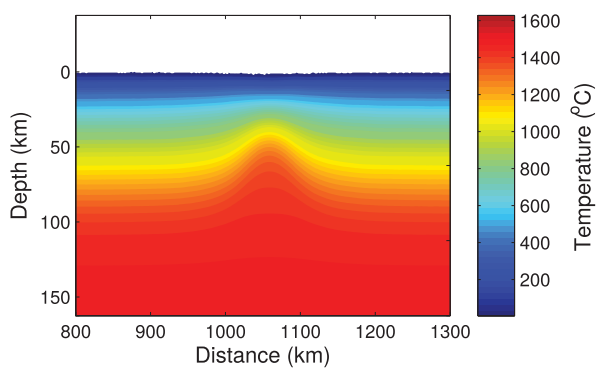

(b) $\mathrm{Tp}=1400^{\circ} \mathrm{C}$, Time $=18.0 \mathrm{Myr}$

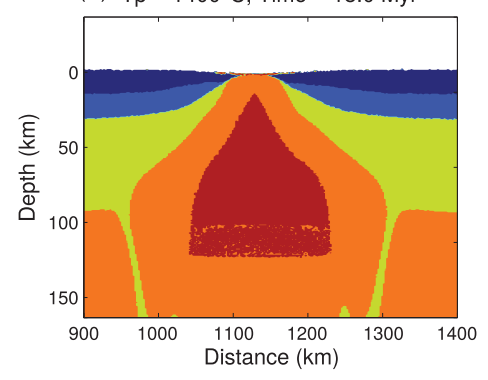

(e)

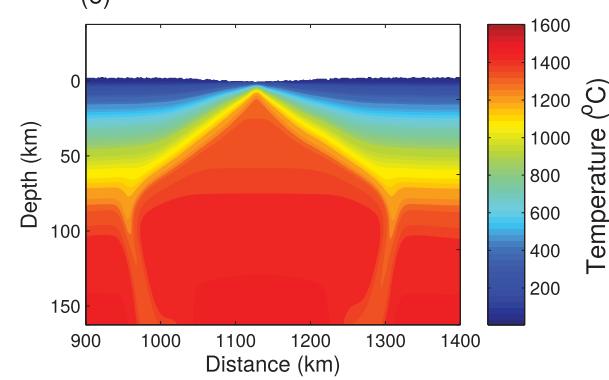

(c) $\mathrm{Tp}=1450^{\circ} \mathrm{C}$, Time $=8.0 \mathrm{Myr}$

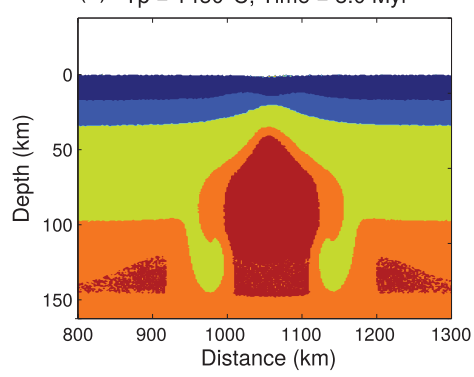

(f)

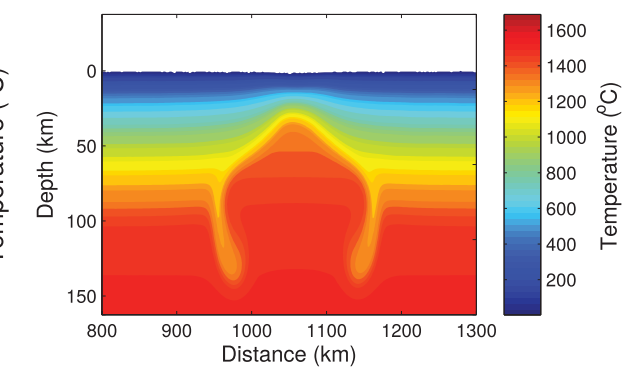

Figure 4. Plots of the crust, lithosphere, asthenosphere and temperature during extension. (a and d) A model at 8 Myr, where the mantle potential temperature is $1,400^{\circ} \mathrm{C}$ and the lower crust is weak. Displayed is the numerical model material markers, where the two dark blues are upper and lower crust. The green region is the lithosphere and the orange region is the asthenosphere. Red regions are the zones of partial melting. (b and e) Same model at $18 \mathrm{Myr}$ where there is a peak in melt production due to the convective breakdown of the lithosphere during extension. (c and f) A model with a hotter mantle potential temperature of $1,450^{\circ} \mathrm{C}$ at 8 Myr. Here the convective breakdown of the lithosphere can be seen to have influence the thinning of the crust when compared with part (a).

during early breakup is plotted against stretch factor for extension at $15 \mathrm{~mm} \mathrm{yr}^{-1}$ (Figure 5). If we make the transformation from time to stretch factor, there is no longer a significant difference between the trends of melt generation vs. stretch factor for different crustal strengths (Figure 5).
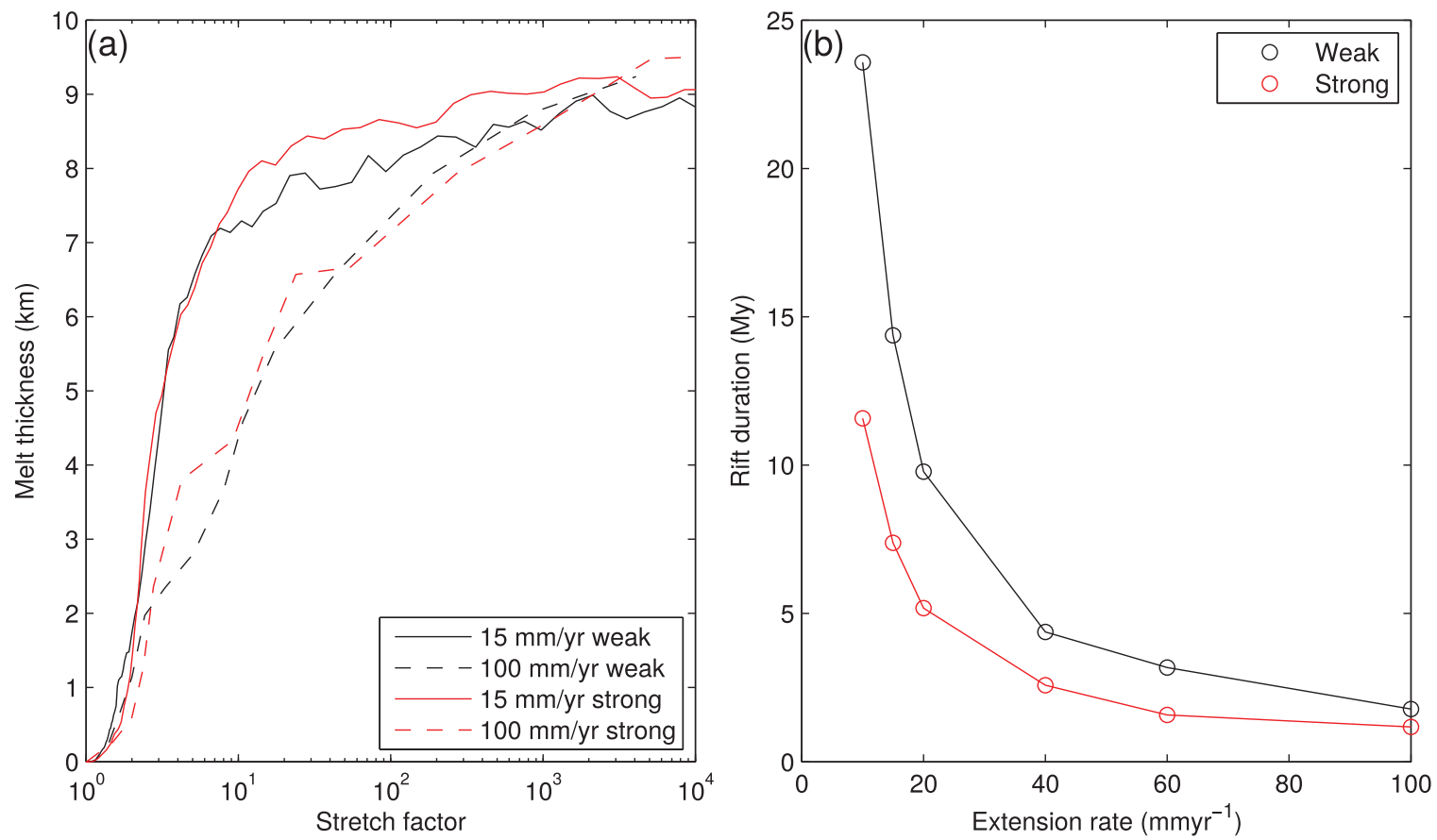

Figure 5. Effect of rate of extension on melt generation (a) Melt thickness plotted against stretch factor for full rates of extension of 15 and 100 mm yr ${ }^{-1}$ and a mantle potential temperature of $1,350^{\circ} \mathrm{C}$. (b) Duration of extension, measured as the time to reach a melt thickness of $8 \mathrm{~km}$, which is the steady-state thickness (see part a). The mantle potential temperature is $1,350^{\circ} \mathrm{C}$ for all model runs. 
The rate of extension will also control the duration of extension required to achieve breakup (e.g., Bown \& White, 1995). To calculate this duration we use the model time taken to generate $8 \mathrm{~km}$ of igneous crust. For the models with a mantle potential temperature of more than $1,400^{\circ} \mathrm{C}$, melt production does not simply evolve to steady state but is perturbed by the generation of convective instabilities forming from the base of the lithosphere (Figures $3 a$ and 4). Therefore, to explore the combined effects of the rate of extension and crustal rheology we will focus on a mantle potential temperature of $1,350^{\circ} \mathrm{C}$ (Figure 5), which is close to that required to match the global trend of oceanic subsidence (Petersen et al., 2015).

When the model with a faster rate of extension is compared to the model with a slower rate of extension we observe that $8 \mathrm{~km}$ of magmatic crust is created at larger stretch factors for the faster rate of extension (Figure 5a). The strength of the crust has however little noticeable effect on the relationship between stretch factor and igneous crustal thickness (Figure 5a). The duration of extension before at least $8 \mathrm{~km}$ of magmatic crust is produced is however a function of both rate of extension and crustal strength (Figure $5 b)$. This is due to the greater influence of conductive cooling at slow rates of extension, and also because at slow rates of extension lower crustal flow can become more efficient and promote the formation of a wide rift (Buck, 1991).

At low rates of extension the crustal strength has the largest impact on altering the rift duration (Figure 5b). If the rate of extension is $15 \mathrm{~mm} \mathrm{yr}^{-1}$ for a strong lower crust the duration of rifting is $7.4 \mathrm{Myr}$ while for weak lower crust it is doubled to $14.4 \mathrm{My}$ (Figure 5b). This doubling of the duration of extension is also seen in the trend of thinning continental crust (Figure 3b). If the rate of extension is $60 \mathrm{~mm} \mathrm{yr}^{-1}$ then for strong lower crust the duration is 2.2 Myr compared to 3.2 Myr for weak lower crust (Figure 5b). Therefore at faster rates of extension the strength of the crust has a smaller influence on the rift duration.

\subsection{Melt Chemistry and Crustal Strength}

The geometry of the zone of partial melting is also affected by the strength of the crust during the model evolution (Figure 2). Changes in the distribution of depth of melting will affect the ratio of light to heavy REE, indicative of a smaller role of deep melting in the garnet stability field. To explore how such ratios vary we plot $\mathrm{La} / \mathrm{Yb}$ and $\mathrm{Sm} / \mathrm{Yb}$ against stretch factor for the models of strong and weak lower crust at a rate of extension of $15 \mathrm{~mm} \mathrm{yr}^{-1}$. We plot the ratio of $\mathrm{La} / \mathrm{Yb}$ and $\mathrm{Sm} / \mathrm{Yb}$ to show how the melt chemistry changes with time and increased melt thickness (Figure 6).

First, we verify that a mantle potential temperature in the range 1,350 to $1,400^{\circ} \mathrm{C}$ generates $\mathrm{La} / \mathrm{Yb}$ and $\mathrm{Sm} /$ $\mathrm{Yb}$ ratios that agree with mid-ocean ridge MORB samples (Figures $6 \mathrm{a}$ and $6 \mathrm{~b}$ ). Furthermore, the model implies that mantle temperature has an effect on the melt chemistry. For a mantle potential temperature of $1,450^{\circ} \mathrm{C}$, and a weak lower crust, a La/Yb ratio of 5 is reached when the melt thickness is roughly $8 \mathrm{~km}$ (Figure $6 \mathrm{c}$ ). For the same La/Yb ratio the melt thickness is roughly $14 \mathrm{~km}$ for the strong case (Figure $6 \mathrm{c}$ ). For a mantle potential temperature of $1,350{ }^{\circ} \mathrm{C}$ the same $\mathrm{La} / \mathrm{Yb}$ ratio is reached when the melt thickness is roughly $4 \mathrm{~km}$ and the difference in thickness is not as significant (Figure 6c).

Strength of the crust also affects how melt thickness varies with melt composition. For example at a mantle potential temperature of $1,450^{\circ} \mathrm{C}$, the stronger model generates a greater thickness of melt, by roughly $5 \mathrm{~km}$, that would have the same bulk ratio of La to $\mathrm{Yb}$ (Figure $6 \mathrm{c}$, green and dark red lines). The ratio of the less compatible elements, $\mathrm{Sm} / \mathrm{Yb}$, shows a similar trend with melt thickness (Figure 6d).

\subsection{1-D Melt Models With Constant Thickness Continental Lids}

Models with a strong crust tend to thin uniformly throughout the lithosphere, and therefore, the melt generating zone continuously grows vertically (Figures 2a-2c), causing average depth of melting to decrease and average depletion to increase. This is reflected in rapidly decreasing La/Yb (Figure 7a, red line). Extension models with weak crust, however, produce more rapid thinning of the mantle lithosphere than the crust, and therefore average depth of melting and depletion, and hence the above-mentioned REE ratio decrease is protracted (Figure 7a, blue line).

The effect of weak continental crust superimposing a melting mantle is approximated by calculating REE ratios for 1-D situations, where constant-thickness, non-melting continental lids of either 30 or $50 \mathrm{~km}$ are assumed (Figures $7 \mathrm{~b}$ and $7 \mathrm{c}$ ). The rate of reduction in $\mathrm{La} / \mathrm{Yb}$ is slower for the deeper lid (Figure 7c). This is because the deeper lid acts to reduce the most shallow and productive melting, and so the melt 
(a)

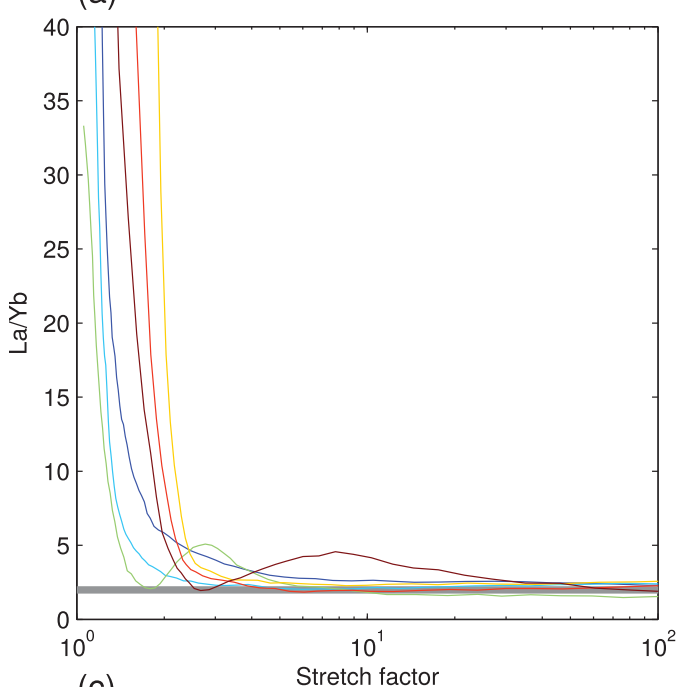

(c)

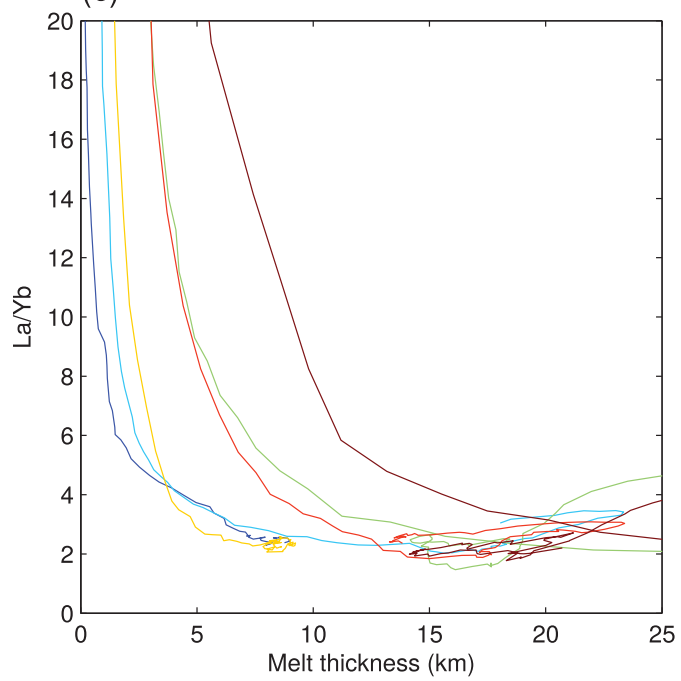

(b)

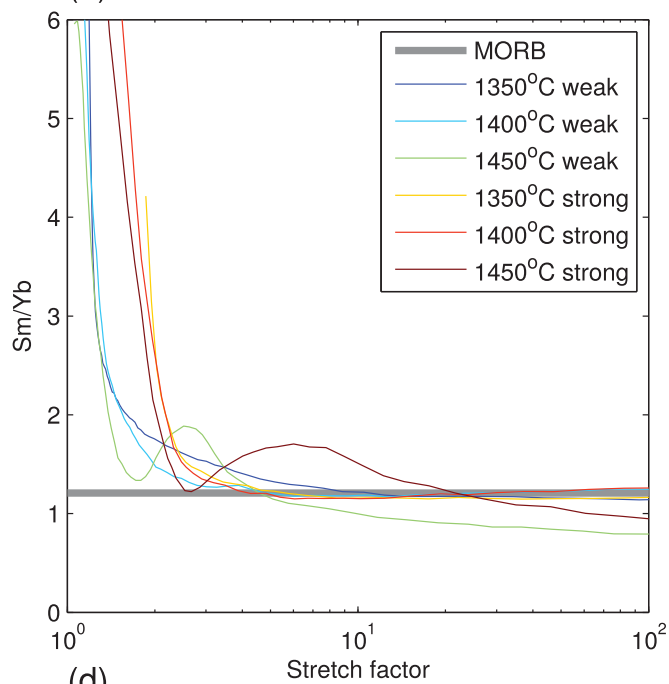

(d)

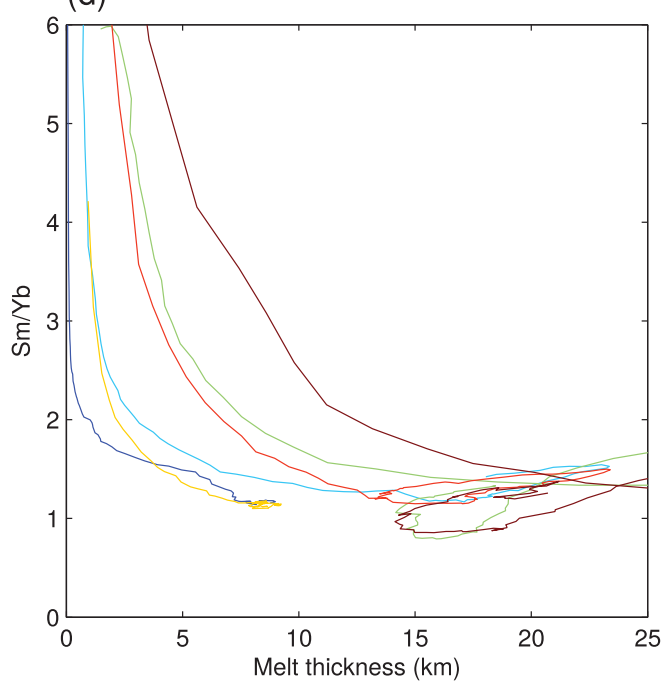

Figure 6. Melt composition as a function of stretch factor and melt thickness for a set of six models that are all of an extension rate of $15 \mathrm{~mm} \mathrm{yr}^{-1}$. The mantle temperature is either $1,350,1,400$ or $1,450^{\circ} \mathrm{C}$ and the lower crust is either strong or weak (see Figure 1). (a) The ratio La/Yb plotted as a function of stretch factor. The average composition of MORB from the Indian Ocean (Klein, 2003) is plotted as the thick gray line. (b) As part a but for the ratio Sm/Yb. (c) The ratio $\mathrm{La} / \mathrm{Yb}$ plotted as a function of melt thickness. (d) As part a but for the ratio $\mathrm{Sm} / \mathrm{Yb}$.

composition remains enriched in light elements. This idealized 1-D model and the full 2-D thermo-mechanical model differ in the sense that the crustal lid is eventually stretched and removed (Figure 7c). Therefore, the REE ratios of the 1-D model converge to the same value regardless of the initial crustal configuration (Figure 7c). Another difference between the 1-D and 2-D models is that the zone of melting has a near triangular 2-D geometry, but with a relatively wide base in 2-D models (Figure 2), whereas the 1-D model only represents the thickest column of the melt zone. The integrated melt composition predicted from the 1-D model therefore depends on specific assumptions about the geometry of the melt zone.

\section{Discussion}

The numerical model suggests that the temporal evolution in REE depletion is a function of the crustal strength, as the weak and strong crustal models predict different evolutions of REE composition against stretch factor (Figure 6). We now therefore test our 2-D model against observed REE compositions from three regions: the southern Basin and Range, the southern Gulf of California, and the Main Ethiopian Rift. 


\section{QAGU Geochemistry, Geophysics, Geosystems}

(a)

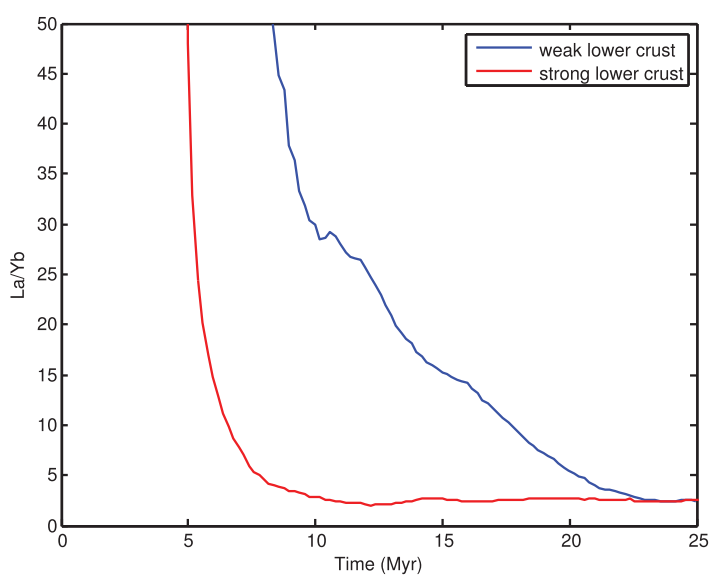

(b)

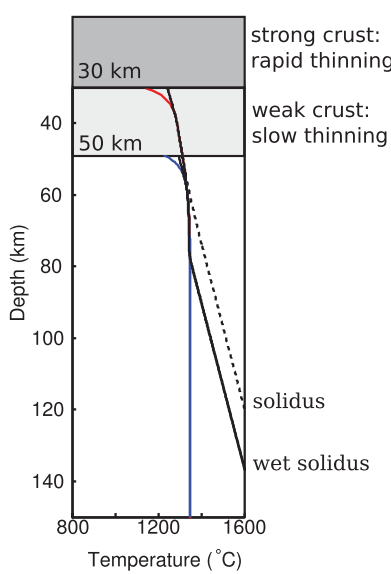

(c)

1D Melting Model

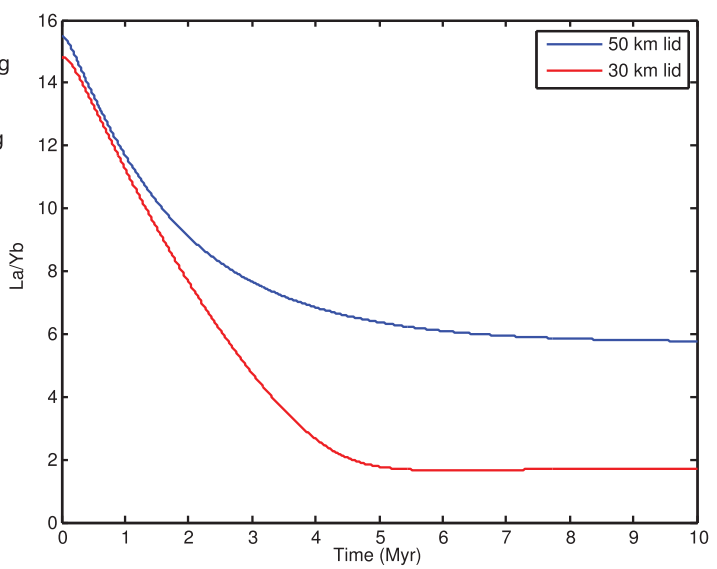

Figure 7. Comparison of the effect of a lid on the zone of partial melting and the full effects of the different lower crustal strength. (a) Model predictions of the evolution of $\mathrm{La} / \mathrm{Yb}$ for the 2-D thermo-mechanical model for the strong and weak lower crust. The extension rate is $10 \mathrm{~mm} \mathrm{yr}^{-1}$ and the mantle potential temperature is $1,350^{\circ} \mathrm{C}$. (b) Two geotherms at $10 \mathrm{Myr}$ from the 1-D melting model where the mantle potential temperature is $1,350^{\circ} \mathrm{C}$ and up-welling is uniform at $5 \mathrm{~mm} \mathrm{yr}^{-1}$. The red line shows the geotherm if there was a 30-km thick lid that limits melt generation. The blue line is the equivalent for a $50 \mathrm{~km}$ thick lid. (c) Model predictions for the evolution of La/Yb for the 1-D melting models. The slow reduction in La/Yb is seen for both a thick lid and a weak crust. This is because both scenarios limit shallow melting. However, for the fully mechancial model, the lid eventually thins, leading to both strong and weak models reaching the same steady state melt compoisition.

\subsection{Basin and Range}

We can use observations of REE chemistry along with $\mathrm{K} / \mathrm{Ar}$ and ${ }^{40} \mathrm{Ar} /{ }^{39} \mathrm{Ar}$ ages from the Colorado River Trough in the Southern Basin and Range to explore if the model can fit geological observables with reasonable parameters (Figure 8; Bradshaw et al., 1993). The concept is to test if the trend in reduction in REE ratio with time can be matched by the numerical model. We will compare trends, as it is not reasonable to match numerical model time against geological time because the exact timing of the initiation of extension is not known in nature. The Basin and Range province in North America initially formed during the Late Eocene to Early Oligocene. Its formation and the relationship between magmatism, extension, the subduction of the Farallon slab, and the influence of thermal plumes remains unresolved (e.g., Plank \& Forsyth, 2016). However, relatively simple 1-D thermal and 2-D thermo-mechanical numerical models can explain the quantity and composition of the volcanic rocks erupted (e.g., Bradshaw et al., 1993; Harry et al., 1993).

Overall stretch factors in the Basin and Range are only as high as $\beta \sim 2$ (Davis \& Lister, 1988). In the Colorado River Trough the series of volcanic rocks have an average thickness of 1,000 $\mathrm{m}$, and show a clear reduction in the ratio of light to heavy REE with respect to time (Bradshaw et al., 1993; Figures 8b and 8c). At a model rate of extension of $10 \mathrm{~mm} \mathrm{yr}^{-1}$ and a mantle potential temperature of $1,350^{\circ} \mathrm{C}$, which is similar to rift conditions during the formation of the Basin and Range (Figure 8; Harry et al., 1993), we predict that the weak models have a delayed reduction in the REE ratios relative to the strong models (Figure $8 \mathrm{~b}$ and $\mathrm{c}$ ). Furthermore, the REE ratios decrease more rapidly for the strong lower crust models compared to the weak model, because, in the former case, the melt zone becomes rapidly larger with a greater proportion of melting occurring at shallow depths (Figures $8 \mathrm{~b}$ and $8 \mathrm{c}$ ).

If extension began within the Colorado River Trough at roughly $20 \mathrm{Ma}$, the weaker lower crustal model matches the trend in REE composition while at the same time predicting a melt thickness that is similar to the observed thickness of lava flows (Figure 8). The style of extension predicted by this weak model is in line with the overall wide rift that is the Basin and Range. Furthermore, in the Basin and Range a low $\mathrm{Vp} / \mathrm{Vs}$ ratio $(<1.75)$ suggests the presence of a hydrated and quartz-rich, and hence weak lower crust (Lowry \& Pérez-Gussinyé, 2011; Ma \& Lowry, 2017). There is however a limitation with this inference: we have to assume that extension began in the Early Oligocene. Given the complexity of extension within the Basin and Range, this assumption is hard to verify. However, if extension were assumed to have started earlier, in the Late Eocene, neither weak nor strong model would fit the observed chemistry. 
(a)
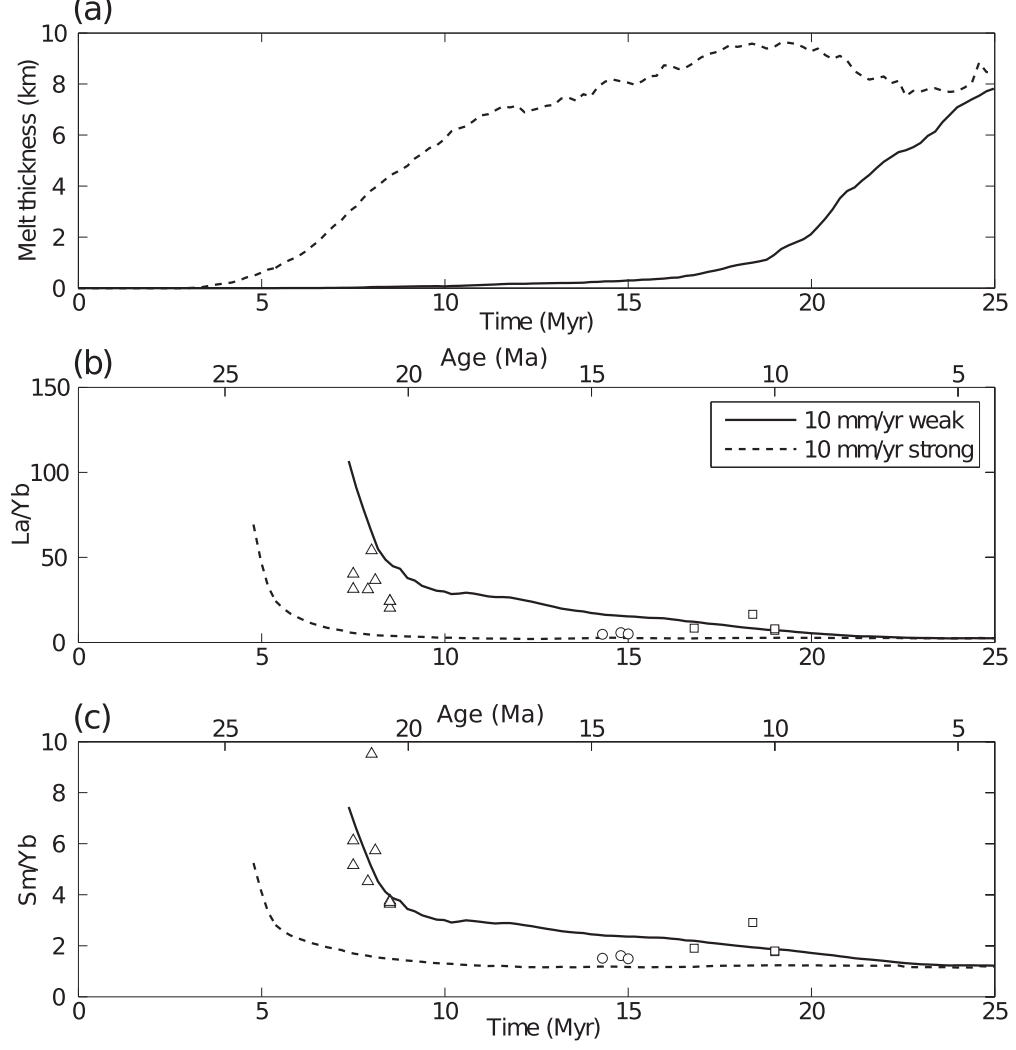

Figure 8. Comparison of the model prediction against observed REE compositions from the Colorado River Trough, Southern Basin and Range (Bradshaw et al., 1993). The extension rate is $10 \mathrm{~mm} \mathrm{yr}^{-1}$ and the mantle potential temperature is $1,350^{\circ} \mathrm{C}$. Both the strong and weak lower crustal rheology is plotted. (a) Melt thickness is plotted against time. (b) The ratio of $\mathrm{La} / \mathrm{Yb}$ plotted against model time. For comparison the observed basalt composition is plotted assuming extension began at $29 \mathrm{Ma}$. The rock compositions and ages are from Bradshaw et al. (1993). Triangles mark their Group 2 syn rift, circles are their Group 2 post rift, and square symbols are their Group 2a rocks. (c) The ratio of Sm/Yb plotted against model time.

\subsection{Gulf of California}

The Gulf of California is a complex zone of oblique extension, where extension in the southern segments may have initiated in the Mid to Late Miocene (Ferrari et al., 2013), and extension along the whole Gulf was fully underway from 12.5 Ma (e.g., Atwater \& Stock, 1998), where current relative motion of the Baja Microplate and the North American plate is between 45 and $47 \mathrm{~mm} \mathrm{yr}^{-1}$ (Plattner et al., 2007). In the model-observation comparison, Figure 9, we assume extension started at $18 \mathrm{Ma}$. In the Sinaloa region toward the south of the Gulf of California, there is a set of dated lavas with REE compositions (Ferrari et al., 2013), which allow for a model comparison. Off-shore of Sinaloa, within the Alarcòn and Capo to Puerto Vallarta transects, the oceanic crust is $5 \mathrm{~km}$ thick (Lizarralde et al., 2007) and the transition from continental to oceanic crust is wide, particularly at the Alarcòn transect (Lizarralde et al., 2007; Sutherland et al., 2012), although this larger width in transition may be partially due to the formation of a failed oceanic basin (Abera et al., 2016).

The wide rift characteristics of the more southerly segments of the Gulf of California might be indicative of a weaker crust. If we plot the composition of crystallized lava flows from the coastal off-shore zone from Sinaloa against age (Ferrari et al., 2013), we observe a gently decreasing trend in La/Yb and Sm/Yb (Figure 9). This trend suggests that the region of partial melting here is becoming gradually more dominated by shallow productive melting, in line with the predictions from models with a weak lower crust (Figure 2). The model prediction for a fixed rate of extension at $20 \mathrm{~mm} \mathrm{yr}^{-1}$ likewise suggests that a weak lower crust is more compatible with the observed melt compositions and wide margin (Figure 9). As with the Basin and Range comparison, the choice of the age of the initiation of extension will also affect the goodness of fit to the chemical data. A greater abundance of dated samples could reduce such uncertainty. 
(a)

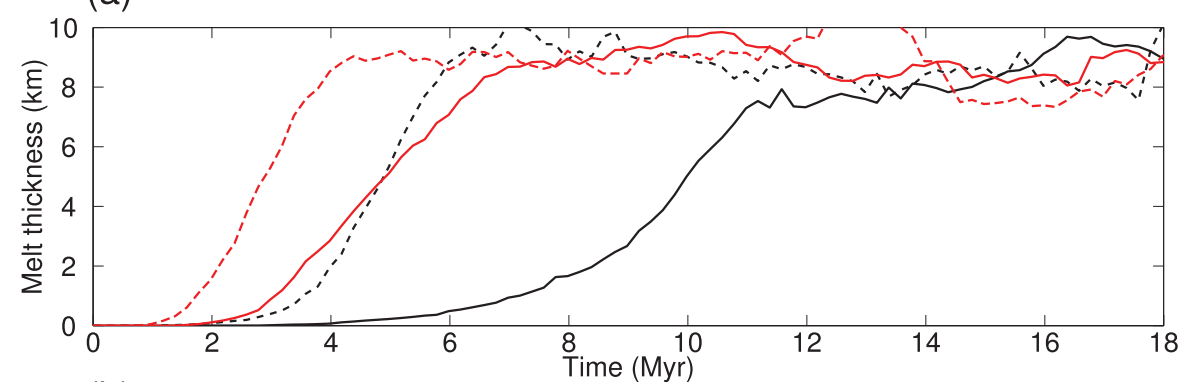

(b)

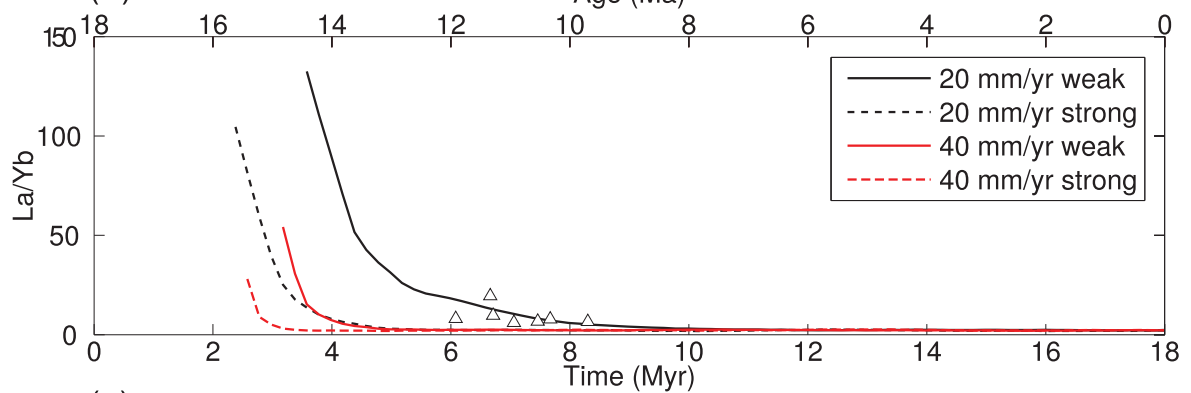

(c)

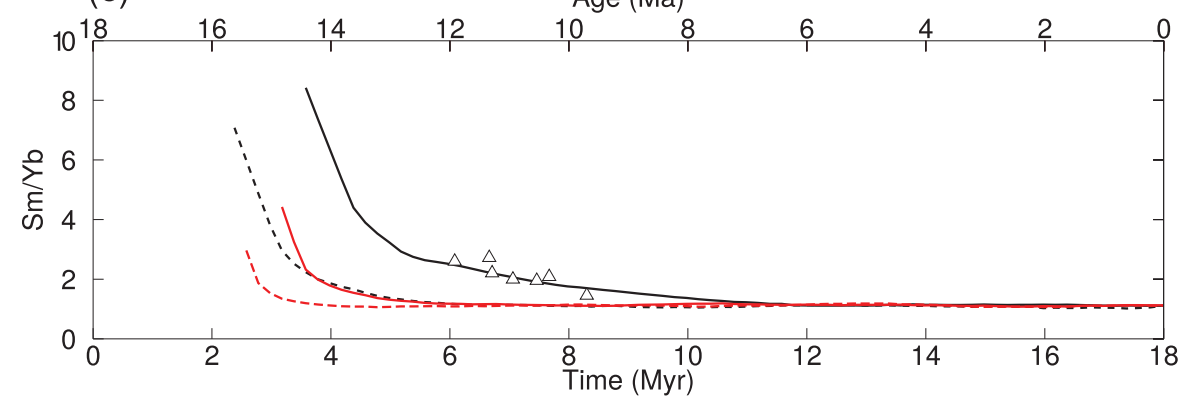

Figure 9. Comparison between a set of four model runs and the composition of basalts erupted in Sinaloa in Baja on the western coast of the southern Gulf of California (Ferrari et al., 2013). The extension rate is either 20 or $40 \mathrm{~mm} \mathrm{yr}^{-1}$ and the mantle potential temperature is $1,350^{\circ} \mathrm{C}$. Both the strong and weak lower crustal rheology is plotted. (a) Melt thickness is plotted against time. (b) The ratio of La/Yb plotted against model time. For comparison the observed basalt composition is plotted assuming extension began at $18 \mathrm{Ma}$. The rock compositions and ages are from Ferrari et al. (2013). (c) The ratio of $\mathrm{Sm} / \mathrm{Yb}$ plotted against model time.

\subsection{Main Ethiopian Rift}

The Main Ethiopian Rift is perhaps the most complex region against which we can compare our 2-D model predictions. The Main Ethiopian Rift has been argued to be a narrow rift within a hot craton (Keranen et al., 2009). This is based on the observation of low S-wave seismic velocities below the region, which can be inferred as being due to a more weak felsic crust $\left(V_{S}\right.$ of 3.7 to $\left.3.8 \mathrm{~km} \mathrm{~s}^{-1}\right)$, and a hot mantle that might contain significant quantities of melt (Keranen et al., 2009) $\left(V_{S}\right.$ low of 4.0 to $4.2 \mathrm{~km} \mathrm{~s}^{-1}$ ). The geometry of extension along the Kenyan and Ethiopian rifts have been matched using a 3-D numerical model that assumed a weak felsic lower crust where the width of the rift zones was a function of the initial condition (Brune et al., 2017b), however this model did not include melt production.

If we model extension of a $100 \mathrm{~km}$ thick lithosphere above an asthenosphere with a $1,350^{\circ} \mathrm{C}$ potential temperature, at a full spreading rate of $10 \mathrm{~mm} \mathrm{yr}^{-1}$, as in the Basin and Range example, a weak crustal model leads to a slow depletion in composition and a prolonged duration of extension (Figure 8). The lithosphere in eastern Africa is roughly 80-120 km thick (Fishwick \& Bastow, 2011), and the rate of extension is roughly $5 \mathrm{~mm} \mathrm{yr}^{-1}$. Therefore, we keep the model initial lithosphere thickness at $100 \mathrm{~km}$ and reduce the rate of extension to $5 \mathrm{~mm} \mathrm{yr}^{-1}$. With this reduced rate of extension, a weak lower crustal configuration generates 
(a)

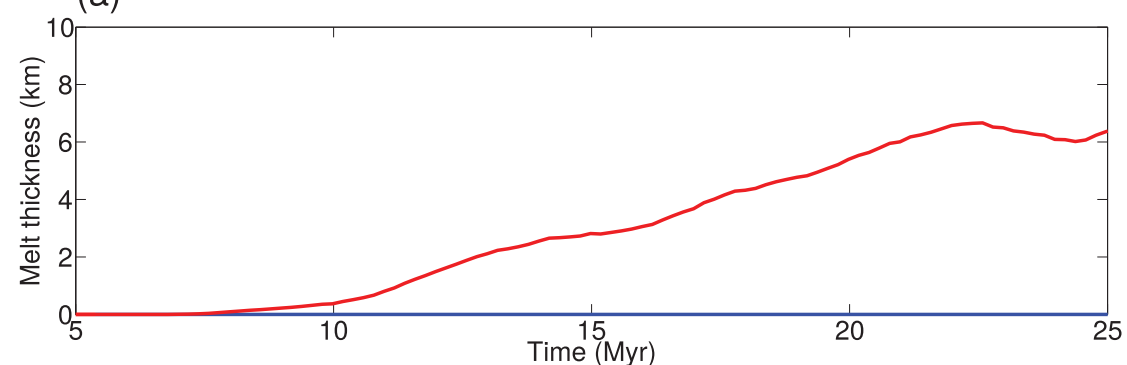

(b)

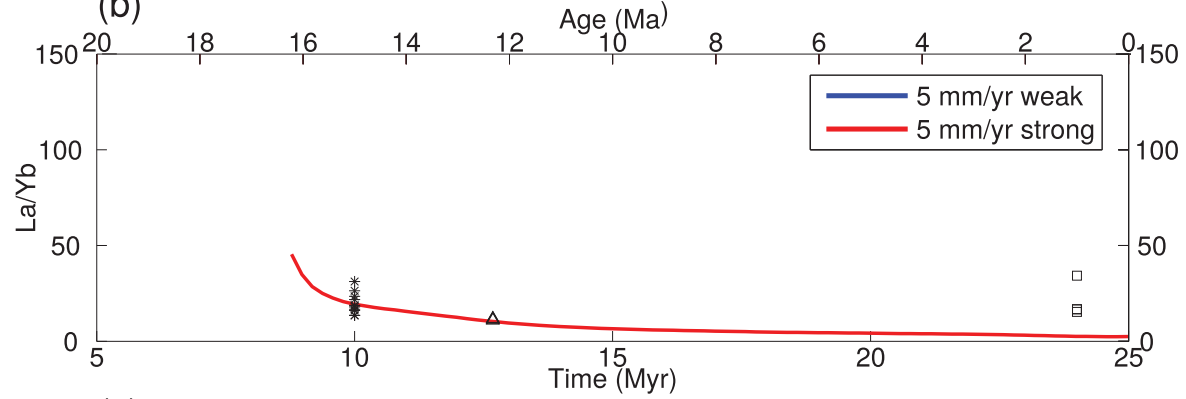

(c)

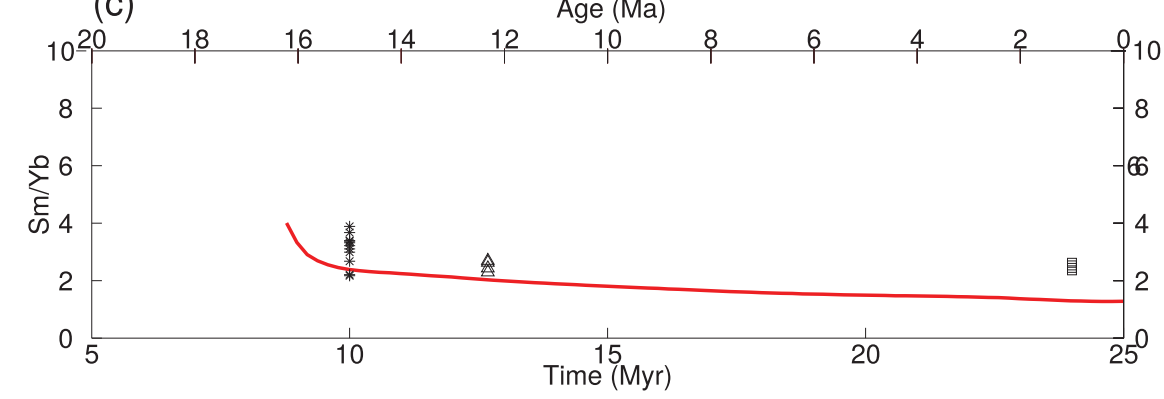

Figure 10. Comparison between two model runs and the composition of basalts erupted in the southern Main Ethiopian Rift (George \& Rodgers, 1998; Rooney, 2010). The extension rate is $5 \mathrm{~mm} \mathrm{yr}^{-1}$ and the mantle potential temperature is $1,350^{\circ} \mathrm{C}$. Both the strong and weak lower crustal rheology is plotted. (a) Melt thickness is plotted against time. Note the weak model predicts no melt generation, so melt thickness is zero. (b) The ratio of La/Yb plotted against model time. For comparison the observed basalt composition is plotted assuming extension began at $25 \mathrm{Ma}$. The rock compositions and ages are: stars, Gerta Kele (George \& Rodgers, 1998); triangles, Chencha (Rooney, 2010); and squares, Arba Minch (Rooney, 2010). (c) The ratio of $\mathrm{Sm} / \mathrm{Yb}$ plotted against model time.

no decompression melting (Figure 10a). This is because strain does not localize and there is insignificant decompression. If however the crust is strong, there is an early localization of strain within the upper mantle, and melting commences after roughly $8 \mathrm{Myr}$ of extension (Figure 10a).

There is relatively little change in the observed ratios of $\mathrm{La} / \mathrm{Yb}$ and $\mathrm{Sm} / \mathrm{Yb}$ from the observed compositions in the southern Main Ethiopian Rift (Figures 10b and 10c): Gerta Kele (15 Ma; George \& Rogers, 2002), Chencha (12 Ma; Rooney, 2010) and Arba Minch (Quaternary; Rooney, 2010). The strong crustal model is capable of matching the observed compositions at Gerta Kele and Chencha (Figures 10b and 10c, stars and triangles), but becomes increasing depleted in the light relative to heavy REEs as the rift evolves. Our model is 2$D$, and does not include any plume source of perhaps more primitive mantle, which may explain why the most recent magmatism in Arba Minch is not as depleted as our model prediction. We also cannot account for processes that cannot be captured in two dimensions, such as localized flow at segment boundaries, which might create localized increased melt generation (Koopmann et al., 2014).

Based on the seismic structure, it has however been argued that the Main Ethiopian Rift is a narrow rift within a hot and weak continental configuration (Keranen et al., 2009). To test this inference we have converted our strong lower crustal forward models to S-wave seismic velocity using methods similar to that described in Goes et al. (2012) and Armitage et al. (2015) (Figure 11). Taking the temperature and pressure 


\section{QAGU Geochemistry, Geophysics, Geosystems}

(a)

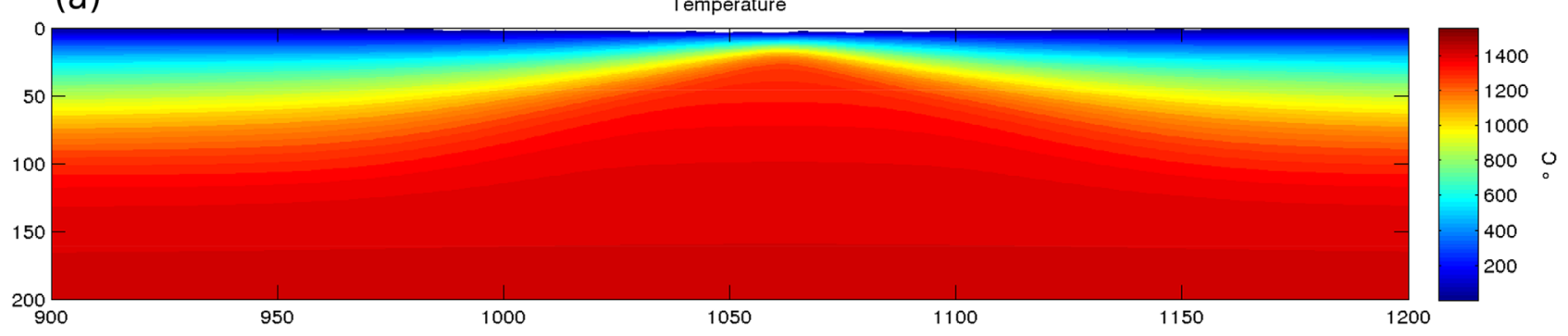

(b)

Melt depletion

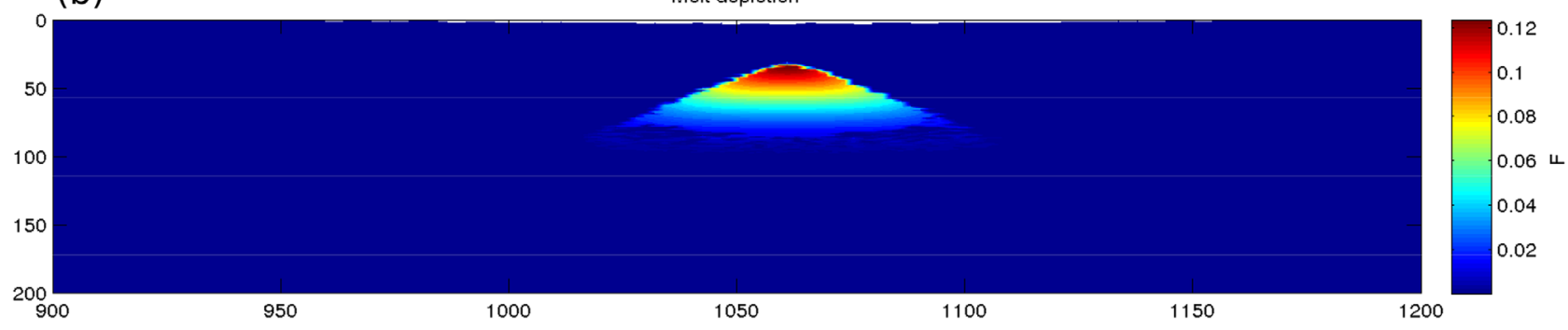

(c)

Vs

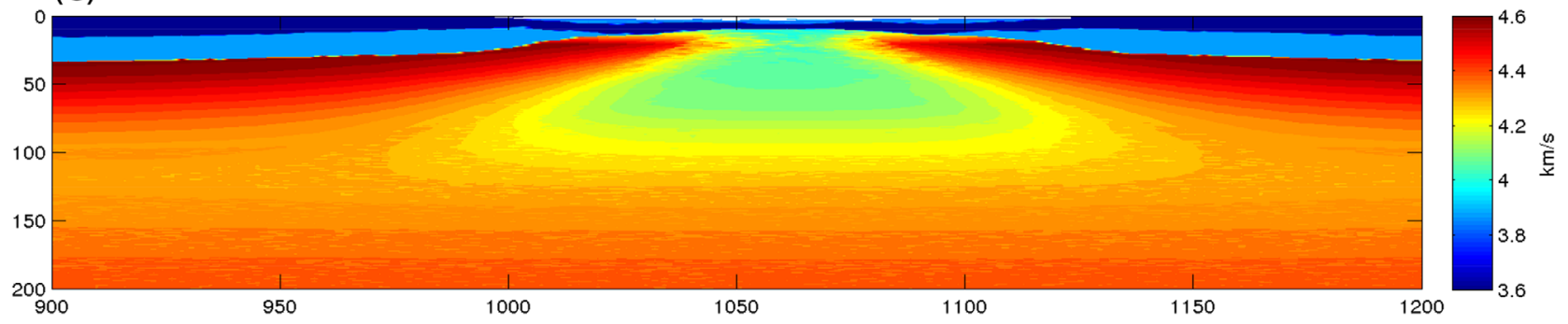

Figure 11. Predicted thermal structure, melt depletion, and S-wave seismic velocity after $25 \mathrm{Myr}$ of extension for the strong lower crust model with an extension rate of $5 \mathrm{~mm} \mathrm{yr}^{-1}$ and mantle potential temperature is $1,350^{\circ} \mathrm{C}$. (a) Temperature, (b) melt fraction and (c) S-wave seismic velocity.

field we calculate the mineral assemblages to estimate the an-harmonic velocity, where the mantle composition is assumed to be pyrolitic for less than $20 \%$ melt depletion, and changes to a pure harzburgite by $20 \%$ melt depletion. In this model there is no melt percolation, however as a minimum estimate for the effect of melt on the seismic wave, the instantaneous porosity generated due to melt production is assumed to reduce the velocity by $-7.9 \%$ per percent porosity (Hammond \& Humphreys, 2000). Finally the anelastic effects of attenuation are included using the attenuation model $Q_{g}$ of Goes et al. (2012). This gives a 2-D prediction of the S-wave seismic velocity structure of the lithosphere and asthenosphere (Figure 11).

By including the effects of attenuation we find that $V_{S}$ in the asthenosphere below the zone of extension is within the range 4.0 to $4.2 \mathrm{~km} \mathrm{~s}^{-1}$ (Figure 11). When the predicted 1-D vertical profile of the S-wave velocity at the center of extension is compared to the range of inversions from the Main Ethiopian Rift, it can be seen that the model is within the range of the observed velocities within the upper mantle (Figure 12, black line). Yet above $50 \mathrm{~km}$ depth the velocities predicted are not as low as the observations. At this shallow depth there is likely a high degree, perhaps 2 to $7 \%$ melt within the uppermost mantle (Hammond \& Kendall, 2016), which will lower the seismic velocity significantly from that predicted from our forward model. Furthermore, low P-wave velocities in the lower crust within the Main Ethiopian Rift are thought to be consistent with the presence of 3 to $5 \%$ melt (Mackenzie et al., 2005). To demonstrate the effect this melt might have on $V_{S}$, we have plotted the effect on the 1-D S-wave profile of the retention of $1 \%$ melt above $40 \mathrm{~km}$ depth (Figure 12, red line), again assuming a reduction of $-7.9 \%$ per percent porosity (Hammond \& Humphreys, 2000). Including the retention of $1 \%$ melt above $40 \mathrm{~km}$ depth creates a very good fit between the model prediction and the observation (Figure 12, red line). 


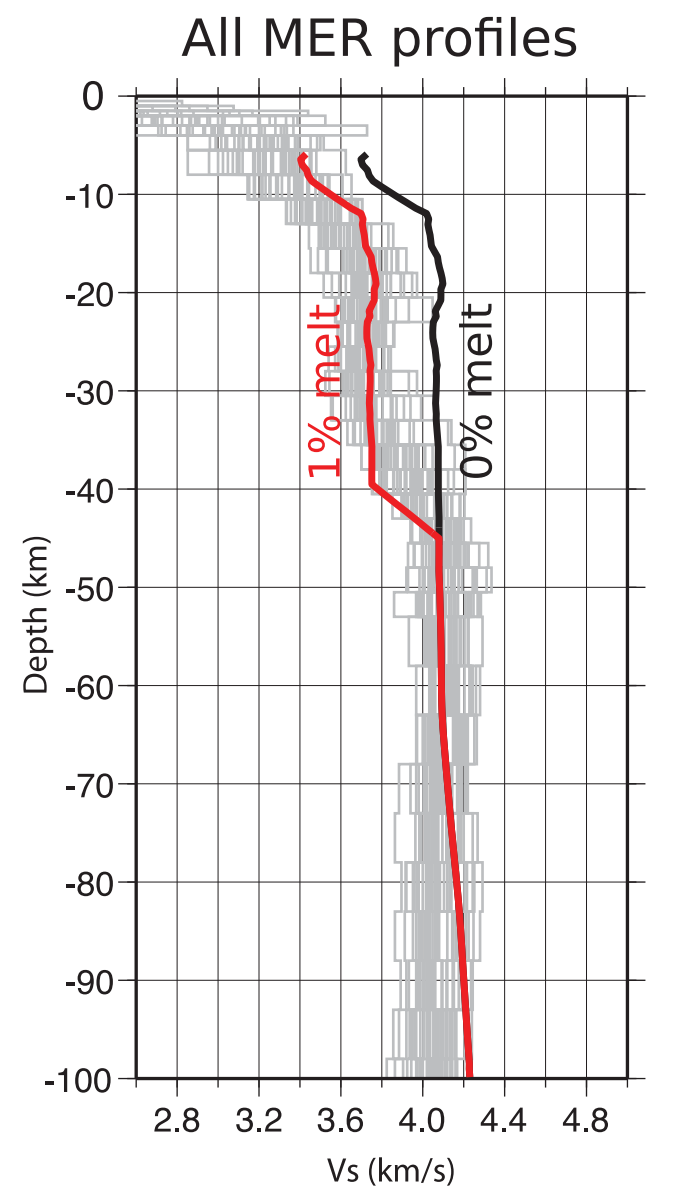

Figure 12. Comparison of the predicted S-wave seismic velocity from the forward model with a strong lower crust (Figure 11c), and the ensemble vertical profiles from the joint inversion of Rayleigh waves and receiver functions below the Main Ethiopian Rift (Keranen et al., 2009). The black line is the model $V_{S}$ assuming no melt storage, the red line assumes that $1 \%$ melt is stored above $40 \mathrm{~km}$ depth.

In summary, when applied to the Main Ethiopian Rift, we find that a strong crust configuration can match observed melt chemistry and S-wave velocities within the upper mantle (Figures 11 and 12). It is possible that the narrow rifting in the Main Ethiopian Rift is due to the weak zones in the pre-rift architecture of the crust and lithosphere (e.g., Brune et al., 2017b), however our models would suggest there is a strong possibility that the Main Ethiopian Rift is a narrow rift because the crust is in fact strong.

\section{Conclusions}

The 2-D numerical model of lithosphere and asthenosphere deformation implies that crustal strength can influence the onset of melt production, and furthermore the composition of melt erupted. The time evolution of the composition of igneous rocks could be used as an indicator of the degree of continental stretching and the strength of the crust. This therefore allows for a quantitative tool when trying to understand what controls the architecture of wide and narrow passive margins. When we apply the model to the the southern Basin and Range and the southern Gulf of California, we find that extension of lithosphere with an initially weak lower crust matches the observed REE composition and wide style of the rift zones.

Comparing the predicted melt chemistry from the 2-D model is clearly challenging given the complex nature of breakup in three dimensions. In particular, we cannot account for important factors such as obliquity and segmentation that may focus melt generation (e.g., Brune et al., 2012; Koopmann et al., 2014), and complex initial conditions that lead to narrow rift architecture in otherwise weak crust (e.g., Brune et al., 2017b). Yet without appealing to initial conditions, for the Main Ethiopian Rift, we find that only with a strong crustal configuration can extension localize sufficiently rapidly given the slow extension rate $\left(5 \mathrm{~mm} \mathrm{yr}^{-1}\right)$. If the crust is weak, there is no melt production, however if the crust is strong the melt produced approaches the observed REE concentrations, and the seismic velocity structure of the upper mantle is within the observed range. This could imply that the Main Ethiopian Rift is in fact a narrow rift within a strong continent. This inference is therefore in line with the more classic idea that strong crust leads to narrow rift zones (Buck, 1991).

Our model demonstrates that crustal structure can determine the onset of volcanism during continental breakup. Furthermore, the crustal structure at the time of breakup leaves a signature behind within the igneous rocks, that is observed within the southern Basin and Range, the southern Gulf of California, and the Main Ethiopian Rift.

\section{Acknowledgments}

This work was funded by an Agence National de la Researche (ANR) research grant "InterRift" awarded to John J. Armitage. Numerical simulations were performed on the S-CAPAD cluster at the Institut de Physique du Globe de Paris. The 2-D thermo-mechanical model is available from https://bitbucket.org/ johnjarmitage/mess. The 1-D melting model used to generate Figure 7 is available from https://bitbucket.org/ johnjarmitage/melt1d-gcubed. The authors wish to thank Sascha Brune and Roger Buck for their reviews that help to improve this manuscript.

\section{References}

Abera, R., van Wijk, J., \& Axen, G. (2016). Formation of continental fragments: The Tamayo Bank, Gulf of California, Mexico. Geology, 44(8), 595-598. https://doi.org/10.1130/G38123.1

Afonso, J. C., \& Ranalli, G. (2004). Crustal and mantle strengths in continental lithosphere: Is the jelly sandwich model obsolete? Tectonophysics, 394(3-4), 221-232. https://doi.org/10.1016/j.tecto.2004.08.006

Afonso, J. C., Zlotnik, S., \& Fernández, M. (2008). Effects of compositional and rheological stratifications on small-scale convection under the oceans: Implications for the thickness of oceanic lithosphere and seafloor flattening. Geophysical Research Letters, 35, L20308. https://doi.org/10.1029/2008GL035419

Armitage, J. J., Collier, J. S., \& Minshull, T. A. (2010). The importance of rift history for volcanic margin formation. Nature, 465(7300), 913917. https://doi.org/10.1038/nature09063

Armitage, J. J., Collier, J. S., Minshull, T. A., \& Henstock, T. J. (2011). Thin oceanic crust and flood basalts: India-Seychelles breakup. Geochemistry, Geophysics, Geosystems, 12, Q0AB07. https://doi.org/10.1029/2010GC003316

Armitage, J. J., Ferguson, D. J., Goes, S., Hammond, J. O. S., Calais, E., Rychert, C. A., \& Harmon, N. (2015). Upper mantle temperature and the onset of extension and break-up in Afar, Africa. Earth and Planetary Science Letters, 418, 78-90. https://doi.org/0.1016/j.epsl.2015.02.039 
Atwater, T., \& Stock, J. (1998). Pacific - North America plate tectonics of the Neogene southwestern United States: An update. International Geology Review, 40(5), 375-402.

Bastow, I. D., Stuart, G. W., Kendall, J. M., \& Ebinger, C. J. (2005). Upper-mantle seismic structure in a region of incipient continental breakup: Northern Ethiopian rift. Geophysical Journal International, 162(2), 479-493. https://doi.org/10.1111/j.1365-246X.2005.02666.x

Behn, M. D., \& Grove, T. L. (2015). Melting systematics in mid-ocean ridge basalts: Application of a plagioclase-spinel melting model to global variations in major element chemistry and crustal thickness. Journal of Geophysical Research: Solid Earth, 120, 4863-4886. https:// doi.org/10.1002/2015JB011885

Berman, R. G., \& Brown, T. H. (1986). Heat capacity of minerals in the system $\mathrm{Na}_{2} \mathrm{O}-\mathrm{K}_{2} \mathrm{O}-\mathrm{CaO}-\mathrm{MgO}-\mathrm{FeO}-\mathrm{Fe}_{2} \mathrm{O}-\mathrm{Al}_{2} \mathrm{O}_{3}-\mathrm{SiO}_{2}-\mathrm{TiO}_{2}-\mathrm{H}_{2} \mathrm{O}-\mathrm{CO}_{2}: \mathrm{Rep}$ resentation, estimation, and high temperature extrapolation. Contributions to Mineralogy and Petrology, 94(2), 262-283. https://doi.org/ 10.1007/BF00379451

Biggs, J., Bastow, I. D., Keir, D., \& Lewi, E. (2011). Pulses of deformation reveal frequently recurring shallow magmatic activity beneath the Main Ethiopian Rift. Geochemistry, Geophysics, Geosystems, 12, Q0AB10. https://doi.org/10.1029/2011GC003662

Bown, J. W., \& White, R. S. (1995). Effect of finite extension rate on melt generation at rifted continental margins. Journal of Geophysical Research, 100(B9), 18011-18029.

Bradshaw, T. K., Hawkesworth, C. J., \& Gallagher, K. (1993). Basaltic volcanism in the southern basin and range: No role for a mantle plume. Earth and Planetary Science Letters, 116(1-4), 45-62.

Brun, J. P. (1999). Narrow rifts versus wide rifts: Inferences for the mechanics of rifting from laboratory experiments. Philosophical Transactions of the Royal Society London A, 357(1753), 695-712.

Brune, S., Corti, G., \& Ranalli, G. (2017b). Controls of inherited lithospheric heterogeneity on rift linkage: Numerical and analogue models of interaction between the Kenyan and Ethiopian rifts across the turkana depression. Tectonics, 36, 1767-1786. https://doi.org/10.1002/ 2017 TC004739

Brune, S., Heine, C., Clift, P. D., \& Pérez-Gussinyé, M. (2017). Rifted margin architecture and crustal rheology: Reviewing IberiaNewfoundland, Central South Atlantic, and South China Sea. Marine and Petroleum Geology, 79, 257-281. https://doi.org/10.1016/j.marpetgeo.2016.10.018

Brune, S., Heine, C., Pérez-Gussinyé, M., \& Sobolev, S. V. (2014). Rift migration explains continental margin asymmetry and crustal hyperextension. Nature Communications, 5, 4014, https://doi.org/10.1038/ncomms5014

Brune, S., Popov, A. A., \& Sobolev, S. V. (2012). Modeling suggests that oblique extension facilitates rifting and continental break-up. Journal of Geophysical Research: Solid Earth, 117, B08402. https://doi.org/10.1029/2011JB008860

Buck, W. R. (1991). Modes of continental lithosphere extension. Journal of Geophysical Research: Solid Earth, 96(B12), $20161-20178$.

Crameri, F., Schmeling, H., Golabek, G. J., Duretz, T., Orendt, R., Buiter, S. J. H., et al. (2012). A comparison of numerical surface topography calculations in geodynamic modelling: An evaluation of the 'sticky air' method. Geophysical Journal International, 189(1), 38-54. https:// doi.org/10.1111/j.1365-246X.2012.05388.x

Davis, G. A., \& Lister, G. S. (1988). Detachment faulting in continental extension; perspectives from the southwestern U.S. Cordillera, GSA Special Publications, 218, 133-160. https://doi.org/10.1130/SPE218-p133

Davis, J. K., \& Lavier, L. L. (2017). Influences on the development of volcanic and magma-poor morphologies during passive continental rifting. Geosphere, 13(5), 1524-1540. https://doi.org/10.1130/GES01538.1

Dean, S. M., Murton, B. J., Minshull, T. A., Henstock, T. A., \& White, R. S. (2008). An integrated kinematic and geochemical model to determine lithospheric extension and mantle temperatures from syn-rift volcanic compositions. Earth and Planetary Science Letters, 278 , 26-39. https://doi.org/10.1016/j.epsl.2008.11.012

Ebinger, C. J., Keir, D., Bastow, I. D., Whaler, K., Hammond, J. O. S., Ayele, A., et al. (2017). Crustal structure of active deformation zones in Africa: Implications for global crustal processes. Tectonics, 36, 3298-3332. https://doi.org/10.1002/2017TC004526

Ferrari, L., López-Martínez, M., Orozco-Esquivel, T., Bryan, S. E., Duque-Trujillo, J., Lonsdale, P., \& Solari, L. (2013). Late Oligocene to Middle Miocene rifting and synextensional magmatism in the southwestern Sierra Madre Occidental, Mexico: The beginning of the Gulf of California rift. Geosphere, 9, 1161-1200. https://doi.org/10.1130/GES00925.1

Fishwick, S., \& Bastow, I. (2011). Towards a better understanding of African topography: A review of passive-source seismic studies of the African crust and upper mantle. In D. J. J. van Hinsbergen, S. J. H. Buiter, \& T. H. Torsvik (Eds.), The formation and evolution of Africa: A synopsis of 3.8 Ga of earth history (Vol. 357, pp. 343-371). London, UK: Geological Society of London. https://doi.org/10.1144/ SP357.19

George, R., \& Rogers, N. (2002). Plume dynamics beneath the African plate inferred from teh geochemistry of the Tertiary basalts of southern Ethiopia. Contributions to Mineralogy and Petrology, 144(3), 286-304. https://doi.org/10.1007/s00410-002-0396-z

Gerya, T. V., \& Yuen, D. A. (2003). Characteristics-based marker-in-cell method with conservative finite-differences schemes for modeling geological flows with strongly variable transport properties. Physics of the Earth and Planetary Interiors, 140(4), 293-318. https://doi.org/ 10.1016/j.pepi.2003.09.006

Gerya, T. V., \& Yuen, D. A. (2007). Robust characteristics method for modelling multiphase visco-elasto-plastic thermo-mechanical problems. Physics of the Earth and Planetary Interiors, 163(1-4), 83-105. https://doi.org/10.1016/j.pepi.2007.04.015

Gibson, S. A., \& Geist, D. (2010). Geochemical and geophysical estimates of lithospheric thickness variation beneath galápagos. Earth and Planetary Science Letters, 300(3-4), 275-286. https://doi.org/10.1016/j.epsl.2010.10.002

Gillet, P., Richet, P., Guyot, F., \& Fiquet, G. (1991). High-temperature thermodynamic properties of forsterite. Journal of Geophysical Research: Solid Earth, 96(B7), 11805-11816. https://doi.org/10.1029/91JB00680

Goes, S., Armitage, J. J., Harmon, N., Huismans, R., \& Smith, H. (2012). Low seismic velocities below mid-ocean ridges: Attenuation vs. melt retention. Journal of Geophysical Research: Solid Earth, 117, B12403. https://doi.org/10.1029/2012JB009637

Hamilton, W. (1987). Crustal extension in the Basin and Range province, southwestern United States. In M. P. Coward, J. F. Dewey, \& P. L. Hancock (Eds.). Continental extensional tectonics (Vol. 28, pp. 155-176). London, UK: The Geological Society London.

Hammond, J. O. S., \& Kendall, J. M. (2016). Constraints on melt distribution from seismology: A case study in Ethiopia. In T. J. Wright, A. Ayele, D. J. Ferguson, T. Kidane, \& C. Vye-Brown (Eds.), Magmatic rifting and active volcanism (Vol. 420, pp. 127-147). London, UK: The Geological Society of London. https://doi.org/10.1144/SP420.14

Hammond, W. C., \& Humphreys, E. D. (2000). Upper mantle seismic wave velocity: Effects of realistic partial melt geometries. Journal of Geophysical Research, 105(B5), 10975-10986.

Harry, D. L., Sawyer, D. S., \& Leeman, W. P. (1993). The mechanics of continental extension in western North America: Implications for the magmatic and structural evolution of the Great Basin. Earth and Planetary Science Letters, 117(1-2), 59-71.

Hirth, G., \& Kohlstedt, D. L. (1995). Experimental constraints on the dynamics of the partially molten upper mantle 2. Deformation in the dislocation regime. Journal of Geophysical Research, 100(B8), 15441-15449. 
Huismans, R., \& Beaumont, C. (2011). Depth-dependent extension, two-stage breakup and cratonic underplating at rifted margins. Nature, 473(7345), 74-78. https://doi.org/10.1038/nature09988

Huismans, R. S., \& Beaumont, C. (2003). Symmetric and asymmetric lithospheric extension: Relative effects of frictional-plastic and viscous strain softening. Journal of Geophysical Research: Solid Earth, 108(B10), 2496. https://doi.org/10.1029/2002JB002026

Ito, G., Lin, J., \& Gable, C. W. (1996). Dynamics of mantle flow and melting at ridge-centred hotspot: Iceland and the Mid-Atlantic Ridge. Earth and Planetary Science Letters, 144(1-2), 53-74.

Jordan, T. H. (1978). Composition and development of the continental tectosphere. Nature, 274(5671), 544-548.

Karato, S., \& Wu, P. (1993). Rheology of the upper mantle: A synthesis. Science, 260(5109), 771-777.

Katz, R. F., Spiegelman, M., \& Langmuir, C. H. (2003). A new parameterization of hydrous mantle melting. Geochemistry, Geophysics, Geosystems, 4(9), 1073. https://doi.org/10.1029/2002GC000433

Keranen, K. M., Klemperer, S. L., Julia, J., Lawrence, J. F., \& Nyblade, A. A. (2009). Low lower crustal velocity across Ethiopia: Is the Main Ethiopian Rift a narrow rift in a hot craton? Geochemistry, Geophysics, Geosystems, 10, Q0AB01. https://doi.org/10.1029/2008GC002293

Klein, E. M. (2003). Geochemistry of the igneous oceanic crust. In H. D. Holland \& K. K. Turekian (Eds.), Treatise on geochemistry (pp. $433-$ 463). Oxford, UK: Elsevier-Pergamon. https://doi.org/10.1016/B0-08-043751-6/03030-9

Koopmann, H., Brune, S., Franke, D., \& Breuer, S. (2014). Linking rift propagation barriers to excess magmatism at volcanic rifted margins. Geology, 42(12), 1071-1074. https://doi.org/10.1130/G36085.1

Lavier, L., \& Manatschal, G. (2006). A mechanism to thin the continental lithosphere at magma-poor margins. Nature, 440(7082), $324-328$. https://doi.org/10.1038/nature04608

Lizarralde, D., Axen, G. J., Brown, H. E., Fletcher, J. M., Gonzalez-Fernandez, A., Harding, A. J., et al. (2007). Variation in styles of rifting in the Gulf of California. Nature, 448(7152), 466. https://doi.org/10.1038/nature06035

Lowry, A. R., \& Pérez-Gussinyé, M. (2011). The role of crustal quartz in controlling Cordilleran deformation. Nature, 471(7338), $353-357$. https://doi.org/10.1038/nature09912

Ma, X., \& Lowry, A. R. (2017). USArray imaging of continental crust in the conterminous United States. Tectonics, 36, 2882-2902. https://doi. org/10.1002/2017TC004540

Mackenzie, G. D., Thybo, H., \& Maguire, P. K. H. (2005). Crustal velocity structure across the Main Ethiopian Rift: Results from twodimensional wide-angle seismic modelling. Geophysics Journal International, 162(3), 994-1006. https://doi.org/10.1111/j.1365-246X. 2005.02710.x

Mackwell, S. J., Zimmerman, M. E., \& Kohlstedt, D. L. (1998). High temperature deformation of dry diabase with application to tectonics on venus. Journal of Geophysical Research: Solid Earth, 103(B1), 975-984. https://doi.org/10.1029/97JB02671

McDonough, W. F., \& Sun, S. S. (1995). The composition of the Earth. Chemical Geology, 120(3-4), 223-253. https://doi.org/10.1016/00092541(94)00140-4

McKenzie, D., Jackson, J., \& Priestley, K. (2005). Thermal structure of oceanic and continental lithosphere. Earth and Planetary Science Letters, 233(3-4), 337-349.

McKenzie, D., \& O'Nions, R. K. (1991). Partial melt distribution from inversion of rare earth element concentrations. Journal of Petrology, 32(5), 1021-1091.

Nielsen, T. K., \& Hopper, J. R. (2004). From rift to drift: Mantle melting during continental breakup. Geochemistry, Geophysics, Geosystems, 5 , Q07003. https://doi.org/10.1029/2003GC000662

Parsons, B., \& Sclater, J. G. (1977). An analysis of the variation of ocean floor bathymetry and heat flow with age. Journal of Geophysical Research, 82(5), 803-827.

Pérez-Gussinye, M., Morgan, J., Reston, T., \& Ranero, C. (2006). The rift to drift transition at non-volcanic margins: Insights from numerical modelling. Earth and Planetary Science Letters, 244(1-2), 458-473. https://doi.org/10.1016/j.epsl.2006.01.059

Peron-Pinvidic, G., Manatschal, G., \& Osmundsen, P. T. (2013). Structural comparison of archetypal atlantic rifted margins: A review of observations and concepts. Marine Petroleum Geoscience, 43, 21-47. https://doi.org/10.1016/j.marpetgeo.2013.02.002

Petersen, K. D., Armitage, J. J., Nielsen, S. B., \& Thybo, H. (2015). Mantle temperature as a control on the time scale of thermal evolution of extensional basins. Earth and Planetary Science Letters, 409, 61-70. https://doi.org/10.1016/j.epsl.2014.10.043

Petersen, K. D., Nielsen, S. B., Clausen, O. R., Stephenson, R., \& Gerya, T. (2010). Small-scale mantle convection produces stratigraphic sequences in sedimentary basins. Science, 329(5993), 827-830. https://doi.org/10.1126/science.1190115

Petersen, K. D., \& Schiffer, C. (2016). Wilson cycle passive margins: Control of orogenic inheritance on continental breakup. Gondwana Research, 39, 131-144. https://doi.org/10.1016/j.gr.2016.06.012

Phipps Morgan, J. (1997). The generation of a compositional lithosphere by mid-ocean ridge melting and its effect on subsequent off-axis hotspot upwelling and melting. Earth and Planetary Science Letters, 146(1-2), 213-232. https://doi.org/10.1016/S0012-821X(96)00207-5

Phipps Morgan, J. (2001). Thermodynamics of pressure release melting of a veined plum pudding mantle. Geochemistry, Geophysics, Geosystems, 2(4), 1001. https://doi.org/10.1029/2000GC000049

Phipps Morgan, J., \& Morgan, W. J. (1999). Two-stage melting and the geochemical evolution of the mantle: A recipe for mantle plum-pudding. Earth and Planetary Science Letters, 170(3), 215-239. https://doi.org/10.1016/S0012-821X(99)00114-4

Plank, T., \& Forsyth, D. W. (2016). Thermal structure and melting conditions in the mantle beneath the Basin and Range province from seismology and petrology. Geochemistry, Geophysics, Geosystems, 17, 1312-1338. https://doi.org/10.1002/2015GC006205

Plattner, C., Malservisi, R., Dixon, T. H., LaFemina, P., Sella, G. F., Fletcher, J., et al. (2007). New constraints on relative motion between the Pacific plate and Baja California microplate (Mexico) from GPS measurements. Geophysical Journal International, 170(3), 1373-1380. https://doi.org/10.1111/j.1365-246X.2007.03494.x

Putrika, K. (1999). Melting depths and mantle heterogeneity beneath Hawaii and the East Pacific Rise: Constraints from $\mathrm{Na} / \mathrm{Ti}$ and rare earth element ratios. Journal of Geophysical Research, 104(B2), 2817-2829.

Ranalli, G. (1995). Rheology of the earth (2nd ed.). London, UK: Chapman and Hall.

Ranero, C., \& Pérez-Gussinyé, M. (2010). Sequential faulting explains the asymmetry and extension discrepancy of conjugate margins. Nature, 468(7321), 294-299. https://doi.org/10.1038/nature09520

Reston, T. J., \& Phipps Morgan, J. (2004). Continental geotherm and the evolution of rifted margins. Geology, 32(2), 133-136. https://doi. org/10.1130/G19999.1

Rooney, T. O. (2010). Geochemical evidence of lithospheric thinning in the southern Main Ethiopian Rift. Lithos, 117(1-4), 33-48. https:// doi.org/10.1016/j.lithos.2010.02.002

Ros, E., Pérez-Gussinyé, M., Araujo, M., Thoaldo Romeiro, M., Andres-Martinez, M. M., \& Morgan, J. (2017). Lower crustal strength controls on melting and serpentinization at magma-poor margins: Potential implications for the South Atlantic. Geochemistry, Geophysics, Geosystems, 18, 4538-4557. https://doi.org/10.1002/2017GC007212 
Salters, V. J. M., \& Stracke, A. (2004). Composition of the depleted mantle. Geochemistry, Geophysics, Geosystems, 5, Q05B07. https://doi.org/ $10.1029 / 2003 G C 000597$

Schmalholz, S. M., Kaus, B. J. P., \& Burg, J. P. (2009). Stress-strength relationship in the lithosphere during continental collision. Geology, 37(9), 775-778. https://doi.org/10.1130/G25678A.1

Scott, D. R. (1992). Small-scale convection and mantle melting beneath mid-ocean ridges. In J. Phipps Morgan, D. K. Blackman, \& J. M. Sinton (Eds.), Mantle flow and melt generation at mid-ocean ridges (Geophysical Monograph 71, pp. 327-352). Washington, DC: American Geophysical Union.

Simon, K., Huismans, R. S., \& Beaumont, C. (2009). Dynamical modelling of lithospheric extension and small-scale convection: Implications for magmatism during the formation of volcanic rifted margins. Geophysical Journal International, 176(1), 327-350. https://doi.org/10. $111 /$ j.1365-246X.2008.03891.x

Sutherland, F. H., Kent, G. M., Harding, A. J., Umhoefer, P. J., Driscoll, N. W., Lizarralde, D., et al. (2012). Middle Miocene to early Pliocene oblique extension in the southern Gulf of California. Geosphere, 8(4), 752-770. https://doi.org/10.1130/GES00770.1

Svartman Dias, A. E., Lavier, L. L., \& Hayman, N. W. (2015). Conjugate rifted margins width and asymmetry: The interplay between lithospheric strength and thermomechanical processes. Journal of Geophysical Research: Solid Earth, 120, 8672-8700. https://doi.org/10. 1002/2015JB012074

Tetreault, J. L., \& Buiter, S. J. H. (2017). The influence of extension rate and crustal rheology on the evolution of passive margins from rifting to break-up. Tectonophysics. https://doi.org/10.1016/j.tecto.2017.08.029

Whaler, K. A., \& Hautot, S. (2006). The electrical resistivity structure of the crust beneath the northern Main Ethiopian Rift. In G. Yirgu, C. J. Ebinger, \& P. K. H. Maguire (Eds.), The Afar Volcanic Province within the East African Rift System, (Vol. 259, pp. 293-305). London, UK: The Geological Society of London.

Xu, Y., Shankland, T. J., Linhardt, S., Rubie, D. C., Langenhorst, F., \& Klasinski, K. (2004). Thermal diffusivity and conductivity of olivine, wadsleyite and ringwoodite to $20 \mathrm{gpa}$ and $1373 \mathrm{k}$. Physics of the Earth and Planetary Interiors, 143-144, 321-336. https://doi.org/10.1016/j. pepi.2004.03.005 